\title{
Bioremediation of arsenic contamination from the environment: New approach to sustainable resource management
}

\author{
Dheeraj Pandey* \\ Sadasivan Mycopathology Laboratory, Department of Botany, University of Allahabad, \\ Prayagraj- 211002 (Uttar Pradesh), India \\ Harbans Kaur Kehri \\ Sadasivan Mycopathology Laboratory, Department of Botany, University of Allahabad, \\ Prayagraj- 211002 (Uttar Pradesh), India \\ Ifra Zoomi \\ Sadasivan Mycopathology Laboratory, Department of Botany, University of Allahabad, \\ Prayagraj- 211002 (Uttar Pradesh), India \\ Ovaid Akhtar \\ Department of Botany, Kamla Nehru Institute of Physical and Social Sciences, Sultanpur \\ - 228118 (Uttar Pradesh), India

\section{Shweta Chaturvedi} \\ K. Banerjee Centre of Atmospheric and Ocean Studies, University of Allahabad, Prayagraj - \\ 211002 (Uttar Pradesh), India \\ *Corresponding author. Email: dheerajpandey817@gmail.com
}

\section{Article Info}

https://doi.org/10.31018/

jans.v13i4.2986

Received: September 6, 2021

Revised: December 7, 2021

Accepted: December 10, 2021

\section{How to Cite}

Pandey, D. et al. (2021). Bioremediation of arsenic contamination from the environment: New approach to sustainable resource management . Journal of Applied and Natural Science, 13(4), 1499 - 1517. https://doi.org/10.31018/jans.v13i4.2986

\begin{abstract}
Present acceleration of Arsenic [As] exposure leads to severe health problems. Modern scientific approaches look towards potent bio-agents for the removal of such types of contaminations in sustainable ways. Microbes can potentially change the redox potential, solubility, $\mathrm{pH}$ by different complex reactions during bioremediation. There are many enzymes present in the microbial system which are involved in methylation such as As (V) reductase, monomethyl arsonic acid reductase, As (III) methyltransferase, and MMA (III) methyltransferase. On the other hand, microbes have As transformation ability and changed into different extractable forms with sulfide minerals such as arsenopyrite (FeAsS), enargite $\left(\mathrm{Cu}_{3} A s \mathrm{~S}_{4}\right)$ and realgar $\left(\mathrm{As}_{4} \mathrm{~S}_{4}\right)$. In some bacteria, the As-operon machinery thiol group bind with As, itdetoxifies its toxicity. Ars $R$ gene and arsenic reductase enzyme (Ars C) play the key role in the reduction of As (V) to As (III) and detoxify by being transported outside of the cell by Ars AB As chemiosmotic efflux system. In fungi, As (V) is reduced to As (III) by the arsenate reductase and GSH glutathione converted into GSSH glutathione disulfide. In plants, As (III) conjugates with phytochelatin (PC) or GSH glutathione and accumulates in the vacuole or is converted into less toxic forms in the presence of arsenic reductase enzyme. This review focused on the potentiality and mechanisms of different microbes for As-detoxification in a sustainable manner.
\end{abstract}

Keywords: Algae, Arsenic [As], AM fungi, Bacteria, Fungi, Hyperaccumulator, Protozoa

\section{INTRODUCTION}

Arsenic [As] is a semi-metallic compound with atomic number 33 in the periodic table. The discovery of As might be in the early Bronze Age (2500 BC). Albertus Mannus (1250) was the first to isolate in the form of arsenic sulfide. As is found on earth in solid grey, yellow and black colours with brittle and relatively low Mohs-hardness. There are four oxidation states viz., -3 , $0,+3$, and +5 of As in which As (0) is elemental form and As (+3) and As (+5) mainly existing forms in the environment. Out of four oxidation states, As $(\mathrm{V})$ is the most stable form (Sharma and Sohn, 2009; Zhao et al., 2010; Gupta et al., 2011). As exists in many different organic forms such as mono-methyl arsenic acid [MMA], dimethyl arsinic acid [DMA], tri-methyl arsineoxide [TMAO], arsenobetaine [AsB], arseno-choline (AsC), arsenosugars (AsS), arsenolipids etc. (Tangahu et al., 2011). Among them, dimethyl arsinous acid and monomethyl arsonous acid are more toxic, whereas As 
(III) is usually more toxic than As (V) in inorganic forms (Mass et al., 2001; Abedin et al., 2002a and b). As (III) can oxidize cysteine residues thiols (-SH) group plays an important role in the citric acid cycle. It can inhibit succinate dehydrogenase activity, ATP production in mitochondria and reduce $\mathrm{NAD}^{+}$during oxidative phosphorylation in plants (Mazumder, 2005). As-toxicity may lead to cancer and its exposer to man kind cause different health problems. IARC (International Agency for Research on Cancer) accepted it as a group first carcinogenic compound. WHO set the standard of As quantity in drinking water that is $0.01 \mathrm{mg} / \mathrm{l}$ whereas Food and Agriculture Organization (FAO) declared permissible limit for As limit $0.10 \mathrm{mg} / \mathrm{l}$ in irrigated water. WHO advisory conference of As scheduled to consider 200-300 ppb for rice. Under normal conditions, Asconcentration in land plants are usually less than 10000 ppb (Matschullat, 2000).

As-contamination comes in the environment by natural as well as man-made sources. Shallow or main aquifers are natural sources and come into the water by rock weathering. However, the present deep water irrigation and other industrial effluents, mining, pesticides, wood preservatives, etc., are other anthropogenic sources. As contamination occurs globally viz., Argentina, Bangladesh, Chile, China, France, Germany, India, USSR, Peru, Namibia, Mexico, Sweden, and USA (Nelson 1977; Mandal and Suzuki, 2002; Shaji et al., 2021) are affected. In South-East Asia, Ganga-MeghnaBrahmaputra (GMB) plains are highly contaminated. The presence of arsenic in groundwater is associated with health issues (Zhang et al., 2020; Medunić et al., 2020). Weak health and poor nutritional condition of the body may accelerate its severity. Exposure to high arsenic water causes ulceration, hyperkeratoses, pigmentation, skin cancer and also affects the kidney, liver, lungs and heart (Sun et al., 2019). In recent years, As contamination has become a serious concern in view of its toxicity to humans being (Shaji et al., 2021). There are various techniques to reduce arsenic contamination in water (Mendoza-Chávez et al., 2020; Nguyen et al., 2020). However, microbes and hyperaccumulator plants play a key role. They transform the As by different activities such as biosorption, bioaccumulation, microbes mediated oxidation-reduction, methylationdemethylation, biostimulation, biovolatilization, bioleaching, biomineralization, biofilm formation. The process of phytoremediation of As can be done through the process of phytostabilization, phytoextraction, and phytovolatilization. This review discusses the various microbes mechanism and ability to remediate As toxicity in a sustainable manner.

Sources of arsenic contamination in the environment

As-contamination has also been reported from
Pre-Cenozoic provinces (Peters et al., 1999). As concentrations in soil, rivers, lakes, estuaries groundwater and marine in different part of the world. Zuzolo et al. (2020) reported groundwater contamination of As from central parts of Italy. According to Medunić et al., (2020) Botswana, Burkina Faso, Ethiopia, Ghana, Morocco, Nigeria, South Africa, Tanzania, Togo, and Zimbabwe are worst affected African countries.

Further, based on some geomorphic and geologic resemblances, As-contaminated regions are subdivided (Mukherjee et al., 2019). For instance, in Asia, most of the affected areas are the Ganges-Brahmaputra in Meghna-plain and delta in India, Bangladesh (Bhattacharya et al., 2007; Das, 2019), Pakistan Indus plain ( Rabbani et al. 2017; Zubair et al., 2018; Ali et al. 2019), Myanmar Irrawaddy delta (WRUD, 2001), Sri Lanka (Chandrajith et al., 2020), Vietnam (Stopelli et al., 2020), Cambodia and Laos Mekong river delta (Feldman et al., 2007). Likewise, some arid and semiarid climatic regions are also reported to be contaminated with a critical level of As. For instance, Argentina (Bhattacharya et al., 2006), the Atacama Desert area of northern Chile (Borgono and Greiber, 1971), and Nevada of the USA (Fontaine, 1994). From the marine sediments, As-contaminated aquifers are reported from Australia,i.e., southeastern parts (Smith et al., 2008) and Taiwan (Tseng et al., 2000). However, As-enriched sulfide mineralization is also a major source of Ascontamination and some of the examples of Ascontaminated area are Ghana (Smedley, 1996), northern Chile (Oyarzun et al., 2004). Nigeria (Gbadebo, 2005), Central Balkan Peninsula in Siberia (Dangic' and Dangic', 2007); Albania (Lazo et al., 2007) and Appalachian belts of northeast USA (Peters, 2008). As contamination in different systems is widespread, it is severe enough to exceed guideline values in many areas. Stroud et al. (2011) reported that As has affected more than 150 million people worldwide with its increasingly elevated concentrations in drinking water. The major As affected regions are presently found in large deltas and along major rivers emerging from the Himalayas, with the Bengal delta being the worst affected area where $>88 \%$ of the 45 million inhabitants are at high risk of exposure to As concentrations >50 lg/l (Acharyya and Shah, 2007; Ravenscroft et al., 2011; Uddin and Huda, 2011).

The sources of As-contamination in the environment include both natural and anthropogenic. Natural sources of As-contamination are by desorption and dissolution of naturally occurring As-bearing compounds adsorbed onto pyrite ores into the water by geochemical factors and over-exploitation of shallow (or main) aquifers. About $90 \%$ of the world production of As was contributed by the countries like China, France, Germany, USSR, Peru, Namibia, Mexico, Swe- 
den, and the USA (Nelson 1977; Mandal and Suzuki, 2002). Anthropogenic sources include, i.e., by use of insecticides, pesticides, herbicides and the use of phosphatic fertilizers, mining, smelting, burning of fossil fuel, timber and feed additives, etc. (Bundschuh et al., 2011; Singh et al., 2015). However, anthropogenic sources exceed by the ratio of 3:1 (Anthropogenic: Natural) in the environment (Woolson, 1983). Some of the examples of important sources of As-contamination are discussed in detail below.

\section{Groundwater}

Over-exploitation of groundwater has been a major source of As problems all over the world. Mexico, USA, China, Bangladesh, Vietnam, and Pakistan were found to be contaminated with As. Very high concentrations of As in groundwater was reported globally (Yoshizuka et al., 2010; Ahn, 2012; Liu et al., 2019; Le Luu, 2019; Shaji et al., 2021).

\section{Minerals}

As occurs as a major constituent in more than 200 minerals and common As- minerals are arsenides, sulfides, oxides, arsenates, and arsenites.. These As-minerals are moderately rare in the natural environment and are usually found in close association with transition metals such as $\mathrm{Au}, \mathrm{Cu}, \mathrm{Pb}, \mathrm{Zn}, \mathrm{Sn}, \mathrm{Ni}$, and $\mathrm{Co}$ in ore zones. Some abundant As-minerals found in the environment are arsenopyrite (FeAsS), realgar (AsS) and orpiment $\left(\mathrm{As}_{2} \mathrm{~S}_{3}\right)$ and it is believed that under the temperature of earth's crust, the formation of arsenopyrite, along with the other abundant mineral such as As-sulphide minerals realgar and orpiment take place (Smedley and Kinniburgh, 1996). It has been reported that China has a large number of As-reserves and it is to be $3977 \mathrm{kt}$, and $2796 \mathrm{kt}$ preserved reserves, of which $87.1 \%$ existed in paragenetic or associated ores up to the end of 2003 (Xiao et al., 2008).

\section{Wood preservatives and desiccants}

In many parts of the world, As such as arsenic acid is widely used as a cotton desiccant. In 1981, FluorChrome-Arsenic-Phenol (FCAP), the first wood preservative, was used in the USA. Later on, in 1964, 2500 tons of arsenic acid $\left(\mathrm{H}_{3} \mathrm{AsO}_{4}\right)$ was used as desiccants on 495,000 ha of US cotton (Fordyce et al., 1995). However, in earlier times, $99 \%$ of the wood preservatives were prepared from Chromated Copper Arsenate (CCA) and Ammoniacal Copper Arsenate (ACA) (Rahman et al., 2004).

\section{Pesticides and herbicides}

As is being extensively used in insect and pest control programs,i.e., for the preparation of an insecticide and pesticides. Many As-compounds are used for the production of cotton as pesticides, such as lead arsenate, copper acetoarsenite, Paris-Green (copper acetoarsenite), calcium arsenate, arsenic acid, monosodium methanearsonate, disodium methanearsonate, and cacodylic acid (National Research Council (US), Environmental Protection Agency, (1980). According to this Counicl, inorganic arsenicals, first and foremost, sodium arsenite, were extensively used in 1890 as weedicide, chiefly for sterilization of non-selective soil. Ure and Berrow (1982) reported very high As concentrations (366-732 mg/kg) in orchard soils due to the historical application of arsenical pesticides to fruit crops.

\section{Feed additives}

According to the European Commission's Feed additives are products used in animal nutrition to improve the quality of feed and the quality of food from animal origin or improve the animals' performance and health. Several compounds which are rich in As are used for feed additives and some of the examples are arsenic acid, 3-nitro-4-hydroxy phenylarsonic acid, 4nitrophenylarsonic acid, etc. (Mandal and Suzuki, 2002).

\section{Drugs}

The medicinal value of $A s$ has been acclaimed for nearly 2500 years. The period between the seventeenth and nineteenth centuries resulted in the development of new As-based drugs, which were applied for the treatment of skin diseases and acute promyelocytic leukemia. arsenic trioxide (ATO, Trisenox) is an important antileukemic drug and malignancy (Chen et al., 1996; Shen et al., 1997; ). There are some medicine, which include As in their medicinal preparations, for instance, potassium arsenite used in Fowler's solution, As and mercuric iodides in Donovan's solution, arsenic trioxide and black pepper in the preparation of Asiatic pills, liquor arsenii chloridi in de Valagin's solution, neoarsphenamine, oxophenarsine hydrochloride (Mapharsen), arsthinol (Balarsen), acetarsone, tryparsamide and carbarsone (Vallee, et al., 1960; Bates et al., 1992; Mandal and Suzuki, 2002).

\section{Mitigation strategies for arsenic contamination}

As is extremely harmful, keeping in view of its toxicity, [As] is categorized as a group first carcinogenic element. The extant exposure of a large population towards As-toxicity is related to the drinking of As contaminated water and agriculture on contaminated soils. So, the reclamation programs are intended to first reduce its toxicity from contaminated water and soils. Modern technologies are being utilized for this purpose (Srivastava et al., 2012; Irshad et al., 2021). Various physical and chemical techniques are available and applied according to their need; however, their effectiveness is in doubt.

Some physical technologies utilize sulfuric acid, nitric 
acid, phosphoric acid, and hydrogen bromide Asdetoxification. While other physical technologies utilize pre-landfilling with cow dung mixture for stabilization and reduction of As (Sullivan et al., 2010). Some selective pore-based separation of molecule membrane technologies viz., microfiltration (MF), ultrafiltration (UF) and nano-filtration (NF), etc., are efficient in the removal of As from water contamination (Figoli et al., 2010). On a very small scale, osmosis membrane (reverse osmosis (RO) or forward osmosis (FO) is being utilized in treatment plants for treating As containing industrial wastes (Cath et al., 2006). Many chemical compounds that are reactive or interact with As are utilized for the As-precipitation as a byproduct. Many oxidant compounds such as chlorine, chlorine dioxide, hydrogen peroxide, chloramine, permanganate, ferrate, and ozone, etc., can precipitate arsenic as in less toxic forms (Lee et al., 2003; Vasudevan et al., 2006; Sharma, 2007; Mondal et al., 2013). Some coagulant agents like alum, ferric oxide, sulfate, etc. help in As removal through the process of coagulation-flocculation (Singh et al., 2015).

The physical and chemical methods described above are practiced on small level remediation because it is not feasible to remediate As from large water bodies or large agricultural fields. Moreover, these techniques are very costly and hard to apply in remote areas. So emerged the concept of bioremediation, where efficient flora and fauna for in situ remediations is used. Soil microbes and plants are utilized for remediation of Ascontaminated soils. Many biochemical processes are reported for As-remediation by these microbes, e.g. bioaccumulation, biosorption, oxidation-reduction, methylation-demethylation, bioleaching, biomineralization, biovolatilization, and biofilm formation, etc. Ashyperaccumulator plants also utilize some mechanisms for the removal of As like phytostabilization, phytoaccumulation, phytovolatilization process. Pteris vittata has been reported as one of the best hyperaccumulor plant $(22,630 \mathrm{mg} / \mathrm{kg}$ ) (Ma et al., 2001).

\section{Arsenic vs. microbial remediation}

With greater public awareness of As-poisoning in animal and human nutrition, there has been growing interest in developing guidelines and remediation technologies for mitigating As contamination in ecosystems. A range of technologies, including chemical immobilization and bioremediation, has been applied with varying levels of success, either to completely remove As from the system or to reduce its bio-toxicity. Bioremediation with special reference to the microbial approach is an emerging technology that uses microbes to remove or stabilize contaminants. It may offer a low-cost and ecologically viable means for the mitigation of heavy metals toxicity in the environment.

Soil microbes thus play a crucial role in environmental As detoxification by biotransformation of inorganic arsenicals into organic forms. Some microbes showed the potentiality of As remediation (Table 1). Soil microbes generally belong to the monera and fungi group, in which many indigenous microbes perform well in the safe removal of As into less hazardous forms. Microor-

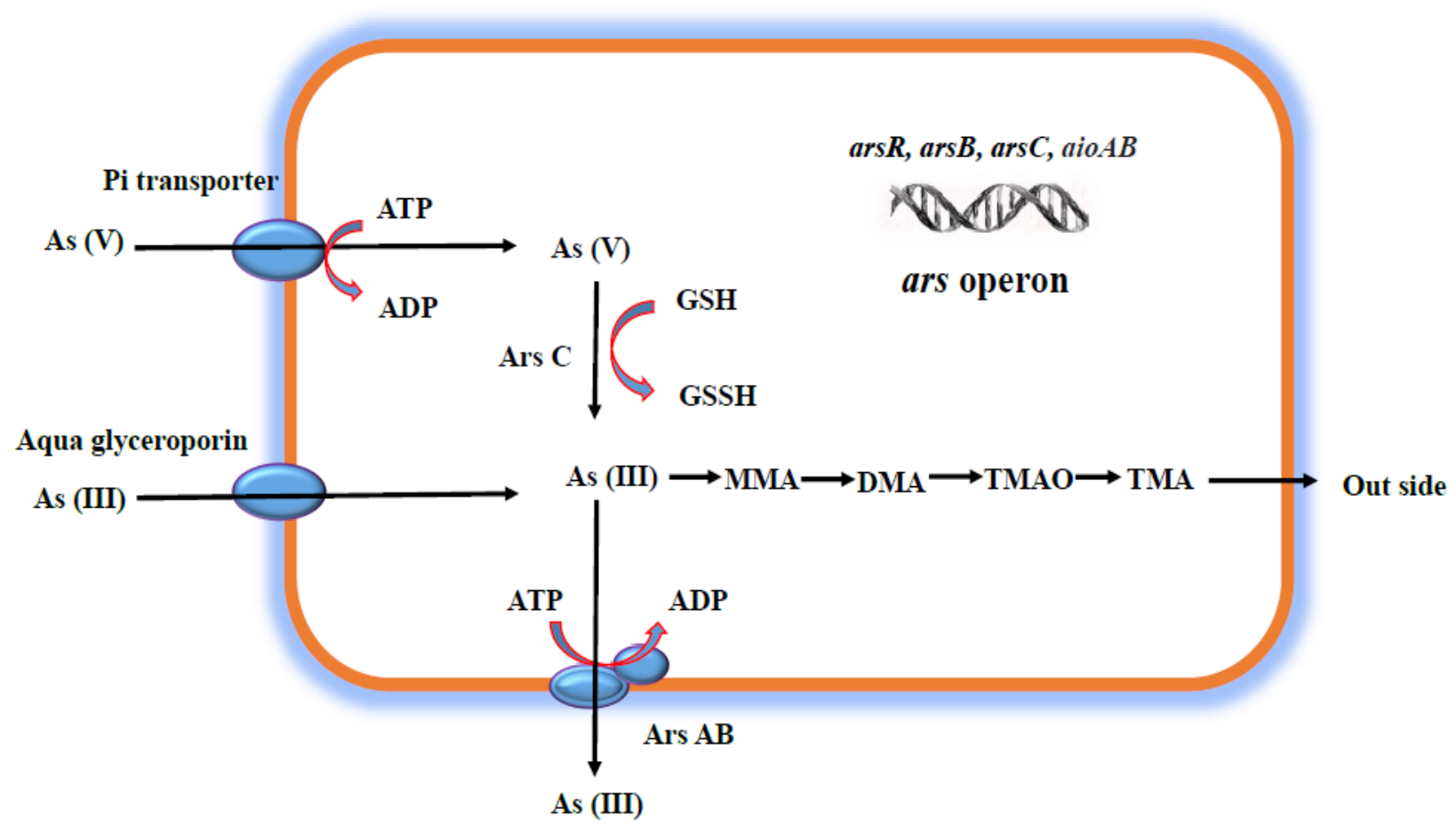

Fig. 1. Mechanism of As-tolerant bacterium for As-detoxification 
Table 1. List of some important microbes showing the potentiality of As remediation

Microbes/Bio-agents
Acidithiobacillus thiooxidans
Acidithiobacillus thiooxi-
dans and A. ferrooxidans
Fusarium oxysporum CZ-8F1,
Penicillium janthinellum SM-
12F4, and Trichoderma
asperellum SM-12F1
Acidithiobacillus ferrooxidans
and $A$. thiooxidans
Acidithiobacillus ferrooxidans
BYQ-12

\section{Bacillus flexus strain As-12}

\section{Nostoc sp. PCC 7120}

\section{Dunaliella salina}

Rhizoglomus intraradices and Glomus etunicatum

\section{Microvirga sp.S-Ml1b}

Kocuria flava AB402 and Bacillus vietnamensis AB403

\section{Ancylobacter sp. TS-1}

Trichoderma sp. MG

\section{Aspergillus flavus}

Bacillus sp. XZM

Bacillus firmus L-148

Bacillus subtilis $\mathrm{S} 4$

\section{Remarks/Conclusions}

Leaching efficiency tended to decrease with increasing temperature due to the decrease in the bacterial growth rate at higher temperature

The results showed that mixed cultures were more efficient than each bacterium for $\mathrm{Cu}$ and $\mathrm{As}$, while $A$. ferrooxidans demonstrated faster extraction efficiency for $\mathrm{Mn}$ and $\mathrm{Zn}$.

All three fungus found capable in As- volatilization, and demethylation.

The maximum As leaching ratio obtained from realgar in the presence of mixed adopted cultures was $28.6 \%$.

The maximum As bioleaching rate was $73.97 \%$ under optimum conditions, and the most effective factor for As leaching was initial ferrous ion concentration.

As-tolerant and efficient remediate As contaminations in vitro conditions.

Workers proposed the biosynthesis pathway of arsenosugar phospholipids production in Nostoc sp. PCC 7120.

The absorption of As (III) or As (V) significantly reduced by an increased phosphate supply.

AM fungi inoculated plants reduced oxidative stress significantly and maintained favorable $\mathrm{P}$ : As ratio.

oxidize arsenite at broad $\mathrm{pH}$ ranges from 4.0 to 9.0

As-resistant halophilic bacterial strains

\section{As-oxidizing bacterium}

This fungus can tolerate high concentrations of $A s(500 \mathrm{mg} / \mathrm{L})$ and $\mathrm{Pb}(650 \mathrm{mg} / \mathrm{L})$ and can help in the bioremediation of metal contaminated soils.

Aspergillus flavus capacity to reduce the mobilization of As in rice and converted As into less toxic forms.

Bacillus sp. XZM found able to reduce As toxicity of Vallisneria denseserrulata.

Bacillus firmus L-148 exhibited a hyper-tolerant and fast As (III) oxidizing nature and this study also confirm the presence of ars and aio operon in cells.

Bacillus subtilis S4 with iron oxide nanoparticles (IONPs) reduced arsenic (As) stress and improve the growth in seedlings of Cucurbita moschata.
References

Lee et al., 2015

Diao et al., 2015

Feng et al., 2015

Leng et al., 2016

Yan et al., 2017

Jebeli et al., 2017

_Xue et al., 2017.

Wang et al., 2017

Sharma et al., 2017

Tapase, and Kodam, 2018

Mallick et al., 2018

Anguita et al., 2018

Govarthanan et al., 2019

Mohd et al., 2019

Irshad et al., 2020

Bagade et al., 2020

Mushtaq et al., 2020 
Table. 1. Contd.....

Fomitopsis betulina

Aspergillus niger strain CBS 140837

AM fungi

AM fungi

Leptolyngbya boryana

Bacillus flexus strain SSAI1

Aspergillus niger strain

Rhizophagus intraradices

Chlorella sp.
Different As species such as As (III), As (V), DMA, TMAO, etc. detected in dried samples of fungus growing on contaminated sites.

This fungus affects the manganese speciation along with bioaccumulation of potentially toxic metals such as As that associated with manganese oxides.

Inoculation of AMF in Pteris vittata improved the As remediation with up to the depth $0-0.2 \mathrm{~m}$ significantly.

As concentration reduced significantly in grains by the inoculation of

AM fungi in Pisum sativum.

Leptolyngbya boryana showed an ability of accumulation, biotransformation of As.

Bacillus flexus strain SSAI1 confirms to have $g l p F$, aioS, aioE, and aioE genes seem to be a potential tool for arsenite bioremediation. Aspergillus niger strain exhibit a significant heavy metal bioextraction capacity from the natural ochres.

Rhizophagus intraradices reduced the toxic effect of As in Triticum aestivum by the promotion of plant growth and As-mediated impairments in plant physiology.

Rice seedlings co-culturing with the Chlorella sp. reduced the

As-toxicity through the enhanced expression of GRX, GST, SAMT genes in plants.
Button et al., 2020

Farkas et al., 2020

Cantamessa

et al., 2020

Alam et al.,

2020

Zhu et al.,

2020

Mujawar et

al., 2021

Urík et al.,

2021

Gupta et al., 2021

Ranjan et al., 2021 ganisms have developed various strategies to counteract As toxicity: like active extrusion of As; intracellular chelation (in eukaryotes) by various metal-binding peptides including glutathione $(\mathrm{GSH})$, phytochelatins (PCs), and metallothioneins (MTs), and As transformation to various organic forms which could be potentially less toxic.

\section{Bacteria as As-remediator}

The prokaryotic cell membrane has hydroxyl, amino, and amide groups, which help in the As sorption (Mukhopadhyay et al., 2002). The mechanism of Astolerant bacterium for As-detoxification has been represented in Fig. 1. Inside the cell, there is As-operon machinery associated with genes and arsenic reductase enzyme (Ars C) and chemiosmotic efflux system that play the key role in the reduction of As (Macur et al., 2001). Many enzymes were discovered in methaneproducing bacteria, including As (V) reductase, monomethylarsonic acid reductase, As (III) methyltransferase, and monomethylarsonous acid methyltransferase, were revealed to be involved in As methylation, according to Wuet al. (2005). Green (1918) was the first to report As-oxidation by using the bacteria Alcaligenes faecalis, Corynebacterium glutamicum term as model As-resistance bacteria in industrial wastewater (Villadangos et al., 2011). Sher et al. (2021) utilized Bacillus licheniformis for mitigating the As toxic effect from contaminated industrial wastewater. Model As-resistant bacteria, Corynebacterium glutamicum tolerant up to $400 \mu \mathrm{M}$ arsenite and another bacteria Pseudomonas aeruginosa PAR 3 show the highest level growth at $200 \mathrm{mg} / \mathrm{l}$ of polluted wastewater (Anyanwu and Ugwu,
2010). Microbacterium lacticum identified as tolerant can tolerate up to $3000 \mathrm{mg} / \mathrm{l}$ arsenites (Pal and Paknikar, 2012). Methanogen bacteria, Methanobacterium bryantii $\mathrm{MOH}$ strain utilized for As biovolatilization for industrial effluent (Stolz et al., 2006).

Enzymatic machinery inside the bacterial cell evolved for energy utilization as well as for the protection of cell. Many enzymes and transporter proteins such as phosphates $(\mathrm{Pi})$ transporter and aquaglyceroporins provide passage to enter inside the cell for As (V) and As (III) respectively whereas, Ars $A$ combined with $\mathrm{B}$ (Ars $A B$ ) make efflux pump which throws As (III) to the environment with ATP driven system (Tripathi et al., 2007). These types of machinery are operated by ars operon that consists of three genes ars $R$, ars $B$, ars $C$ which encode trans-acting repressor, arsenite permease pump, arsenate reductase in cell respectively (Tripathi et al., 2007). The arsenate reductase (Ars C) converts As (V) to As (III) by using glutathione (GSH) as a reducing agent. Lin et al., (2007) identified two additional genes ars $A$ and ars $D$, in some gram-negative bacteria. Inside the bacterial cell, As (III) converted into different organomethenic forms viz., MMA, DMA, TMAO, and TMA and after they finally export to the outer environment. The addition of few other genes were also identified viz., acr 3 , ars $R$, ars $B$ and ars $C$ in Lysinibacillus sphaericus B1-CDA strain (Rahman et al., 2015). Yang and Rosen (2016) recognized another distinguish parallel pathway of As metabolism in the bacterial cell, including ars $M$, ars $I$ and ars $H$ genes for encodes As (III) S-adenosylmethionine methyltransferase, C-As bond lyase, methyl arsenate oxidase, respectively. ArsAB chemiosmotic As-efflux mechanism flung As outside the cell and As (V) reductase (Ars C) 
of small molecular mass (13 to $16 \mathrm{kD}$ ), one of the principal reductive enzymes present in microbial cytoplasm (Silver and Phung, 2005; Macur et al., 2001). Some chemolithoautotrophic microbes utilized [As] as an energy source and an electron donor in process of As (III) oxidation for the reduction and cell growth maintenance (Wang and Zhao, 2009). Some methanogen bacteria demethylated As under anaerobic conditions but it is not stable and rapidly oxidized when coming in contact with oxygen (Kuehnelt and Goessler, 2003).

Under natural conditions, microbial As-demethylation occurs both aerobically as well as anaerobically (Huang et al., 2007). Generally, As-demethylation is not good for remediation (Sierra-Alvarez et al., 2006). Transformation ability of microbes to convert As in different extractable forms in the process of bioleaching ( et al., 2006). Some inorganic elements act as a stimulator to increase microbial As remediation. Márquez et al. (2012) reported role of oxidation of ferrous to ferric ions of sulfide that helps in As extraction. Thiobacillus caldus Thiobacillus ferrooxidans and Leptospirillum ferrooxidans etc. were investigated and have the potency to extract As under optimal laboratory conditions. Elemental sulfur and carbon source accelerated the rate of mitigation of As and helped in their bioleaching from soils or other substrates (Bayard et al., 2006; Mc Lean et al., 2006 Chen et al., (2017) reported bioaugmenta- tion of rice straw $(5 \%)$ with Pseudomonas putida KT2440 increased As volatilization up to 483.2 $\mu \mathrm{g} / \mathrm{kg} /$ year. Mallick et al. (2018) investigated Asresistant halophile bacterial strains Kocuria flava $A B 402$, Bacillus vietnamensis $A B 403$ from Sunderland mangrove and reported strain AB402 and AB403 tolerated $35 \mathrm{mM}$ and $20 \mathrm{mM}$ of arsenite, respectively in vitro conditions. In nature, the mineralization process is involved in the hardening or stiffening of As. Iron, manganese, and sulfide, etc., help in As precipitation in the calcium-rich environment in the form of calcium arsenate $\left[\mathrm{Ca}_{5} \mathrm{H}_{2} \quad\left(\mathrm{AsO}_{4}\right)_{4} \cdot \mathrm{CH}_{2} \mathrm{O}\right]$ (Martínez-Villegas et al., 2013). Soil $\mathrm{pH}$ and indigenous microbial population affect the rate and mineralogical composition of the arsenic-sulfide minerals in groundwater (RodriquezFreire et al., 2016). Pseudomonas putida KT2440 exhibited a high capacity of As-volatilization when applied with rice straw raised arsine fluxes in the reclamation of As-contaminated soils (Chen et al., 2013, 2014, 2017). Mujawar et al. (2021) identified the role of aio $A B$ gene expression association with arsenite oxidase enzyme in Bacillus flexus strain SSAI1.

\section{Fungi as As-remediator}

There are various mechanisms by which fungi tolerate and detoxify metals such as extracellular/intracellular precipitation, complexation, biomethylation, bio-

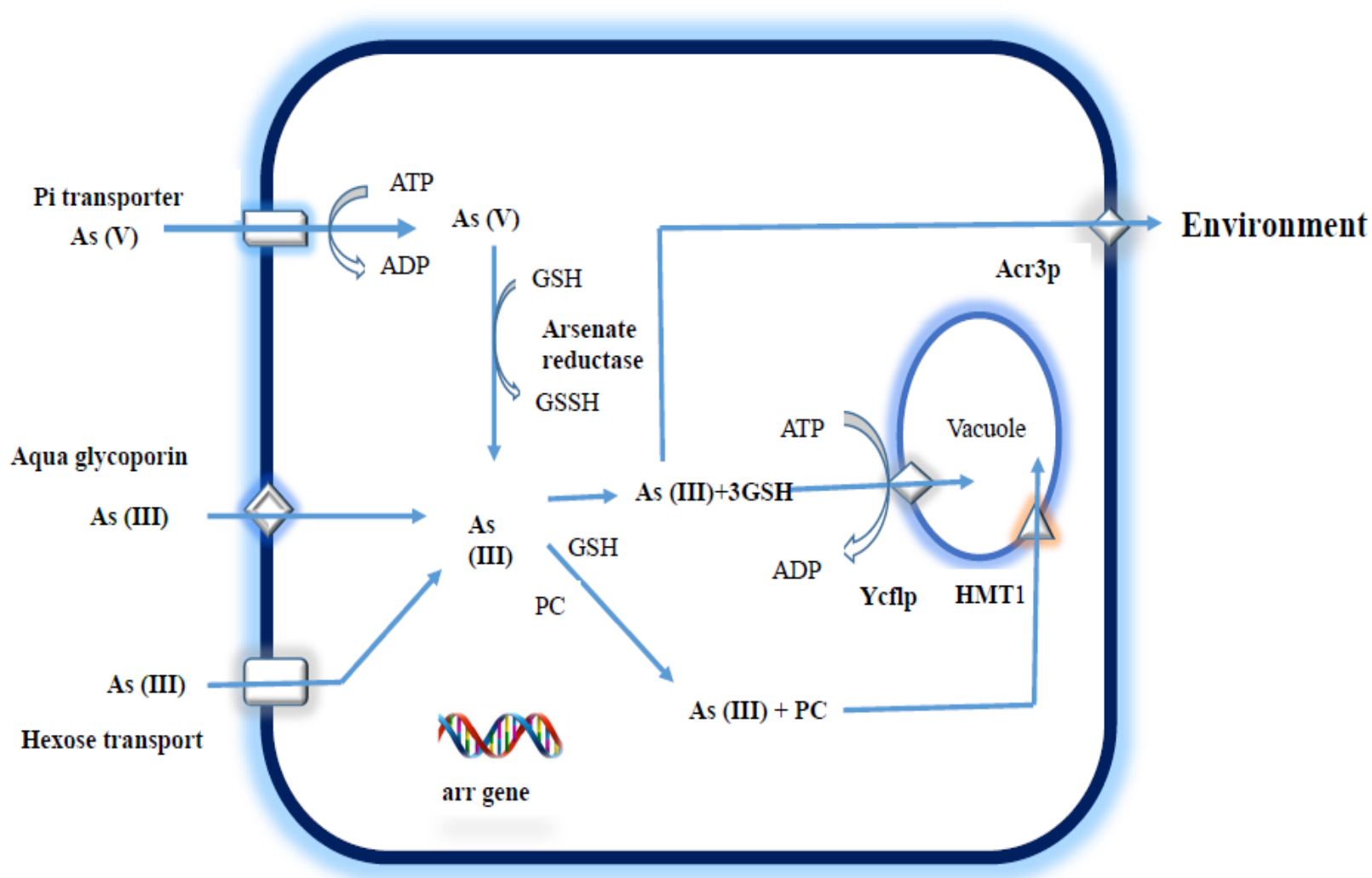

Fig. 2. Mechanism of arsenic tolerant filamentous fungi for As-detoxification 
accumulation, biovolatilization, biosorption, impermeability, active uptake and sequestration. Some of the mechanism arsenic tolerant filamentous fungi for Asdetoxification is represented in Fig. 2. Aqueous arsenite and arsenate from wastewater converted into dimethyl arsine and monomethyl arsine by the application of Penicillium brevicaule, Scopulariopsis sp., Aspergillus glaucus, Candida humicola, and Gliocladium sp. Under aerobic conditions, As (V) enter the fungal cell via the phosphate transporter, whereas aquaporins and hexose provide a passage for As (III) species to enter the cell (Persson et al., 1999; Liu et al., 2004). In the presence of arsenic reductase, glutathione (GSH) was oxidised into glutathione disulfide along with As (V) was reduced to As (III). With the help of transporter proteins HMT1 and YcFIP, conjugated As (III) (with phytochelatin (PC) or GSH glutathione) accumulate in vacuoles (Tsai et al., 2009). The efflux machinery can also expel the conjugated form As (III)$3 G S H$ via the Acr3p protein.

Many fungi, such as Penicillium chrysogenum, Penicillium purpurogenum, and Aspergillus niger, can absorb As from polluted substrate (Loukidou et al., 2003; Pokhrel and Viraraghavan, 2006). Tani et al. (2004) reported that the fungus KR21-2 might accumulate a lot of arsenate during manganese oxide production in the lab. Different fungus species have been found to have both external and intracellular methylation. This As biomethylation converted inorganic to different organic forms, MMA, DMA or TMAO, MMA (III), DMA (III) or gaseous arsines, etc. (Oremland and Stolz, 2003; Jia et al., 2013). Su et al. (2012) reported some fungi reported for their extracellular methylation, such as Apiotrichum humicola, Scopulariopsis brevicaulis, Trichoderma asperellum, Penicillium janthinellum and Fusarium oxysporum intracellular methylation. During the process biomethylation, metal-resistant fungi generated volatile As-species (biovolatilization). Some fungi were reported to generate arsine such as Penicillium sp., Ulpcladium sp., Neosartorya fischeri, Aspergillus clavatus, etc. (Visoottiviseth and Panviroj, 2001; Edvantoro et al., 2004; Čerňanský et al., 2009).

Waghunde et al. (2016), observed that Trichoderma sp. belonging to Ascomycota found more important plant growth-promoting microbes helping in the enhancement of soil fertility and stress tolerance activity. Trichoderma was also capable of increasing plant growth hormone production and root system for uptake of nutrients from the soil. These microbes have a variety of functional groups on the cell surface that allow them to bond with metals. According to Tripathi et al. (2017). Trichoderma sp. potentially improved the chickpea plant under As (V) contamination. Tripathi et al. (2013) added that these fungal microbes were capable of restoring growth deformities as well as induced the nodule formation, chlorophyll content, and proline content in chickpea plants under the high level of As contamination. Caporale et al. (2014), described that $T$. harzianum and $T$. atroviride were reduced the As toxicity level by improved growth and ' $P$ ' uptake in lettuce under As stress conditions. Srivastava et al. (2011) isolated 15 fungal strains from As contaminated soil, belongs to Westerdykella, Aspergillus, Trichoderma, Neocosmospora, Rhizopus, Lasiodiplodia, Sordaria, and Penicillium. They further reported that Westerdykella and Trichoderma were the better performing isolates than Rhizopus and Lasiodiplodia under As stress.

\section{AM fungi as As-remediator}

Arbuscular mycorrhizal (AM) fungi are best known for plant growth-promoting activity and for having remedial activity of several heavy metals (Smith and Read, 2008; Brundrett and Tedersoo, 2018). These AM fungi are obligatory in nature (Bogo et al., 2000) and require lipid during their life span and to complete their life cycle (Bravo et al., 2017; Jiang et al., 2017). In contrast, on a return basis, AM fungi improve the host plant by improving their nutrient status, water uptake and protecting the host plant from other biotic and abiotic stresses (Lenoir et al., 2016). AM fungi were reported from highly metal toxic soils and found associated with metal tolerant plants (Tonin et al., 2001). After struggling with the stress conditions, these AM fungi developed the resistive mechanism against the heavy metals. When these AM fungi were further provided unstressed conditions, they lose their tolerating properties against the heavy metals (Shalaby, 2003). This tolerating property is mainly due to phenotypic plasticity compared to genotypic. Garg and Singla (2012) experimentally observed that the AM colonized pea plant exposed to As (V) showed enhancement in relative water content (higher turgor) and chlorophyll content. They also reported that the AM fungi increase the uptake of sucrose and glycine betaine in the cell and Latef (2011) added that AM fungi also increase the proline content under metal stress conditions.

AM fungi were found to help the plants fight against Asinduced phosphorus deficiency and maintain the P: As ratio in plants by decreasing As-translocation (Spagnoletti et al., 2016). Molecular studies revealed that up-regulation of RiPT showed a high affinity with AM fungi and RiArsA, a putative efflux pump in rice plants under high As treatments (Wu et al., 2015). Pathare et al., (2016) indicated that the specific genes are involved in AM fungi-mediated As toxicity amelioration in rice plants. The AM fungi inoculation was found to tackle As stress with a decrease in As (V) uptake, increase in plant growth, and N, P, K levels (Garg and 
Singla, 2012).

Smith and Read (2008) reported that AM fungi often protect plants against high concentrations of nonessential metals, in addition to the improvement of ' $P$ ' status and uptake of some essential elements resulting in greater plant biomass. This is due to arsenate As (V), which has great similarity in chemical behavior to phosphate. It is thought that AM fungi may also influence As dynamics in soils. Triticum aestivum plants associated with AM fungi exhibited much better growth and were healthier than non-associated plants under contaminated soil (Sharma et al., 2017; Gupta et al., 2021). AM fungi also enhance the expression of phosphate transporter genes (PHT1) in many plants (Chen et al., 2007). These PHT1 genes were isolated from As (V) tolerant Arabidopsis thaliana (Catarecha et al., 2007). These AM fungi i.e. species of Glomus suppressed high-affinity arsenate and phosphate transport into the roots. Conversely, mycorrhizal association with the fern Pteris vittata has been reported to stimulate more As accumulations (Liu et al., 2005). Jankong and Visoottiviseth (2008) experimentally reported that As concentration was lowered in petioles of plants treated with AM fungi as compared to non-treated plants. The effect of AM fungi in the reme- diation of heavy metal stress is well known. Mechanism of the potential of AM fungi adopts amelioration of heavy metal including As has been presented in Fig. 3 . In rhizospheric soil, AM fungi release glomalin that binds heavy metal in soil, and also binds in their cell wall components. This process plasma membrane act as a barrier (Khan, 2005). Different chelators present in cytosol, e.g., metallothioneins, organic acids, amino acids, and metal-specific chaperons, act on entering heavy metal and sequestration into the vacuole and also export to plant (hyperaccumulator) help in phytoremediation. (Göhre and Paszkowski, 2006). Plant-AM fungi symbiosis is mutual and contributes resource exchange nutrient transfer, water transfer, and sometimes carbon transfer to plant, but AM fungi' effectiveness varies from plant to plant (Johnson et al., 2002; Nottingham et al., 2010). AM hyphal network makes a broad network and reaches beyond the deficit zone from the root and absorbs nutrients, water, and other trace nutrients in limiting soil and also regulates carbon dynamics ecosystem (Clemmensen et al., 2013). For the proper growth of plants especially reproductive phase development phosphorus $(P)$ is very important, generally in immobilized form (orthophosphate) in soils. AM fungi are well known as $\mathrm{P}$-solubilizer and store ' $\mathrm{P}$ ' as poly-

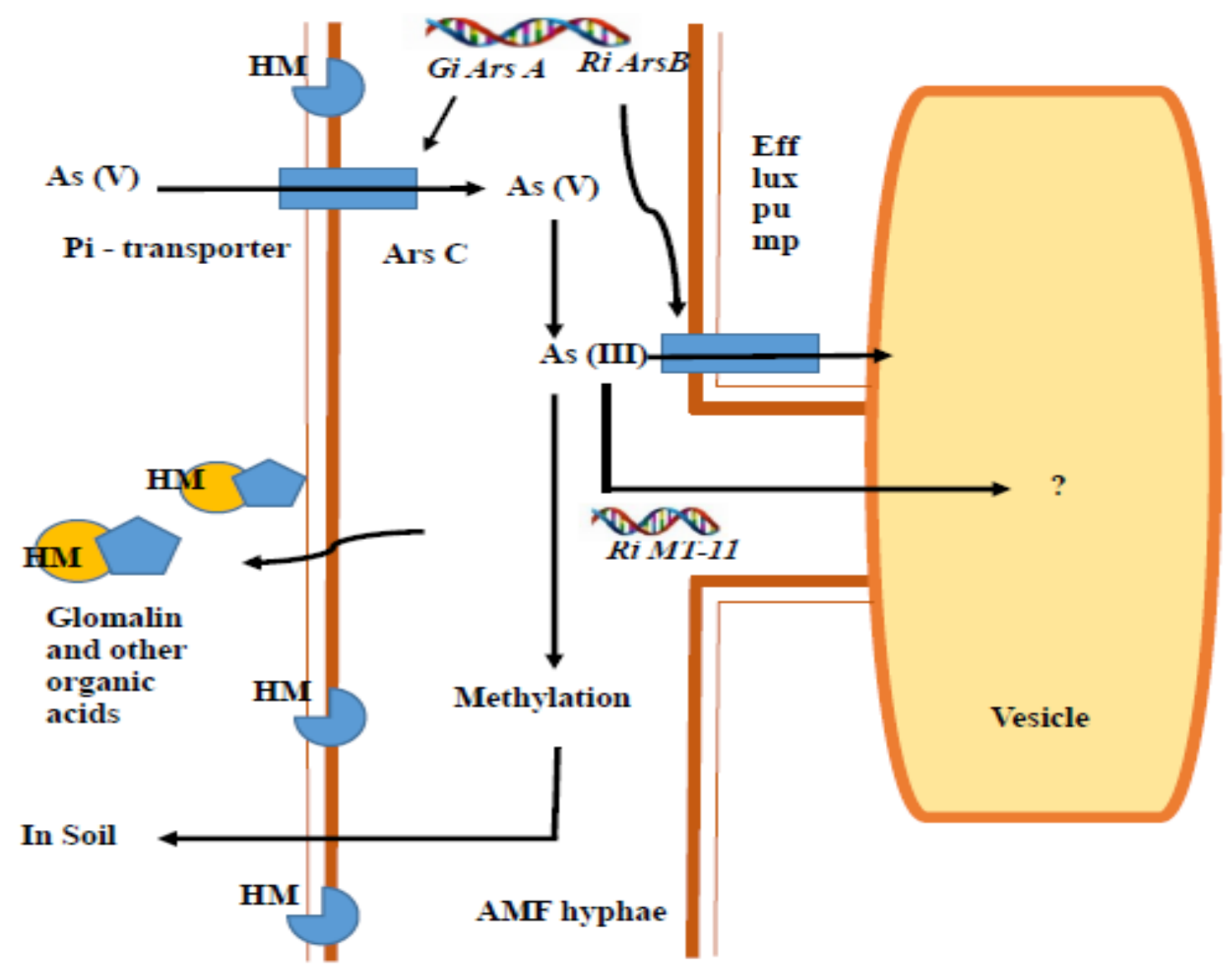

Fig. 3. Mechanism of potential AM fungi adopt amelioration of heavy metal including As (HM = heavy metals) 


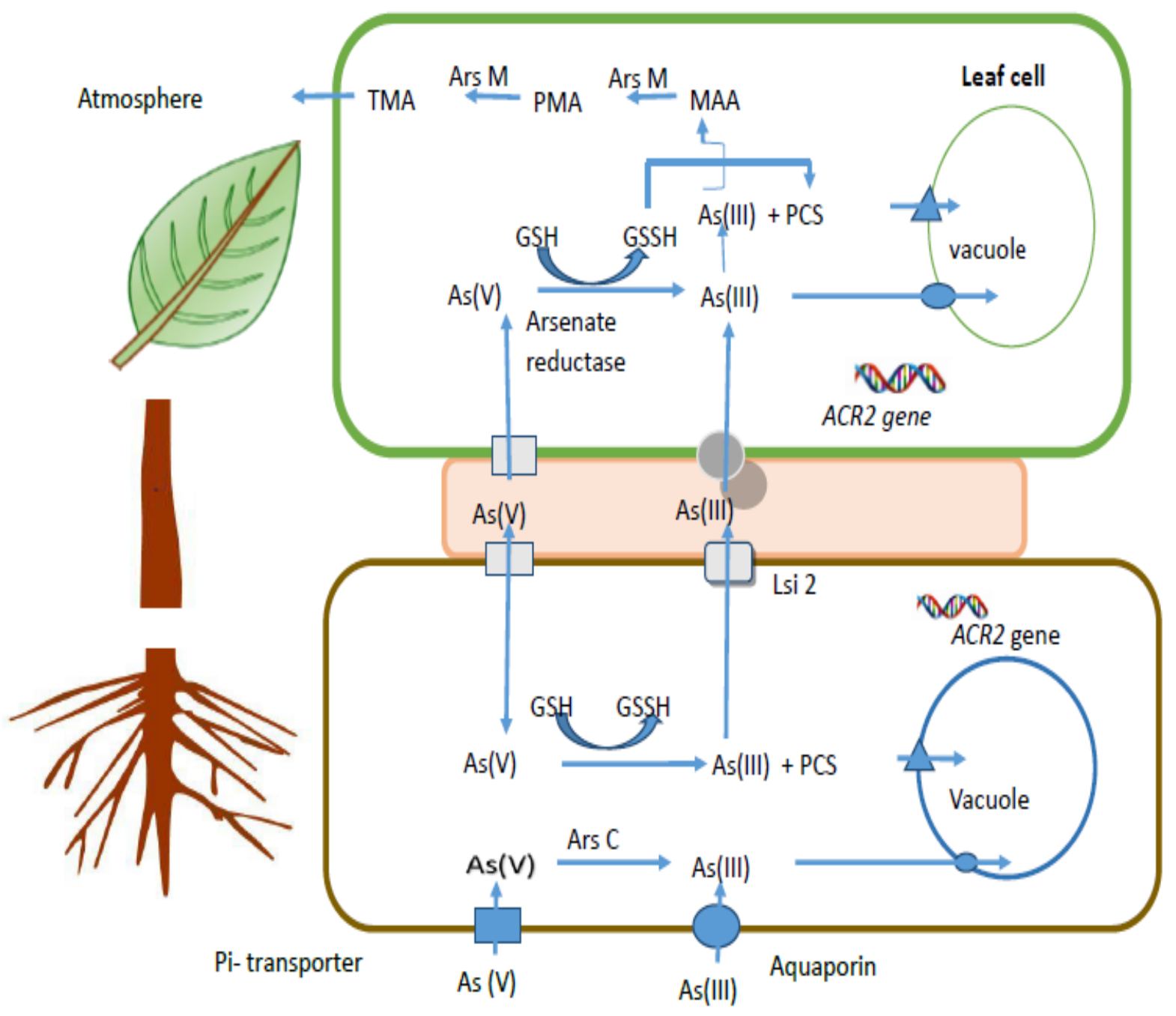

Fig. 4. Mechanism of As-detoxification by the As-tolerant/hyper accumulator plants

phosphate, which helps keep relatively low $\mathrm{Pi}$ concentration in AM hyphae, so the proper ' $P$ ' transfer to plant root cell maintained (Hijikata et al., 2010).

As and ' $P$ ' belong to the same group of elements in the periodic table and ' $P$ ' is a chemical analog of As and utilized the same transporter for their entry into root cell (Wu et al., 2011). Cozzolino et al., (2010) reported the inoculation of native AM fungi in consortium with ' $P$ ' increased plant biomass and noticed a decrease in As accumulation in plants. Pigna et al. (2010) revealed that ' $P$ ' can elevate As toxicity in wheat-growing in As contaminated soils.

Researches specify the As a metal import, transportation, detoxification, etc., within hypha and discoveries of specific genes which are present to regulate the transportation, reduction, efflux pumping, etc. Two novel genes have been discovered i.eRiArsB and RiMT11 involved in As detoxification in AM fungi (Zhang et al., 2015; Maldonado-Mendoza and Harrison, 2018).

RiMT-11 gene was discovered in Rhizophagus irregu- laris and the other one GiArs $A$ was also described previously in the same species which involved in As intake through phosphate transport channel (GonzálezChávez et al., 2011). RiArsB gene is associated with As (III) efflux pump towards outside of mycelia. It would be part of Ars $A B$, whereas RiMT-11 gene plays a role in methylation of As (Maldonado-Mendoza and Harrison, 2018). Christophersen et al. (2012) investigated the effect of AM fungi symbiosis in Medicago truncatula amended with As (V) and ' $\mathrm{P}$ ' and concluded that the expression of MtPT4 gene was maximum in plant inoculated Glomus mosseae while MtPHT1; 1 expressed maximum in plant inoculated with Glomus intraradices. Further, they reported that the inoculation of the $G$. mosseae enhanced the uptake of ' $P$ ' as compared to As by the application AM fungi. These genes were coded arsenate/arsenite permease component and As methyltransferase, respectively. Li et al. (2021) experimented that Rhizophagus irregularis symbiosis successfully remediate the As from 


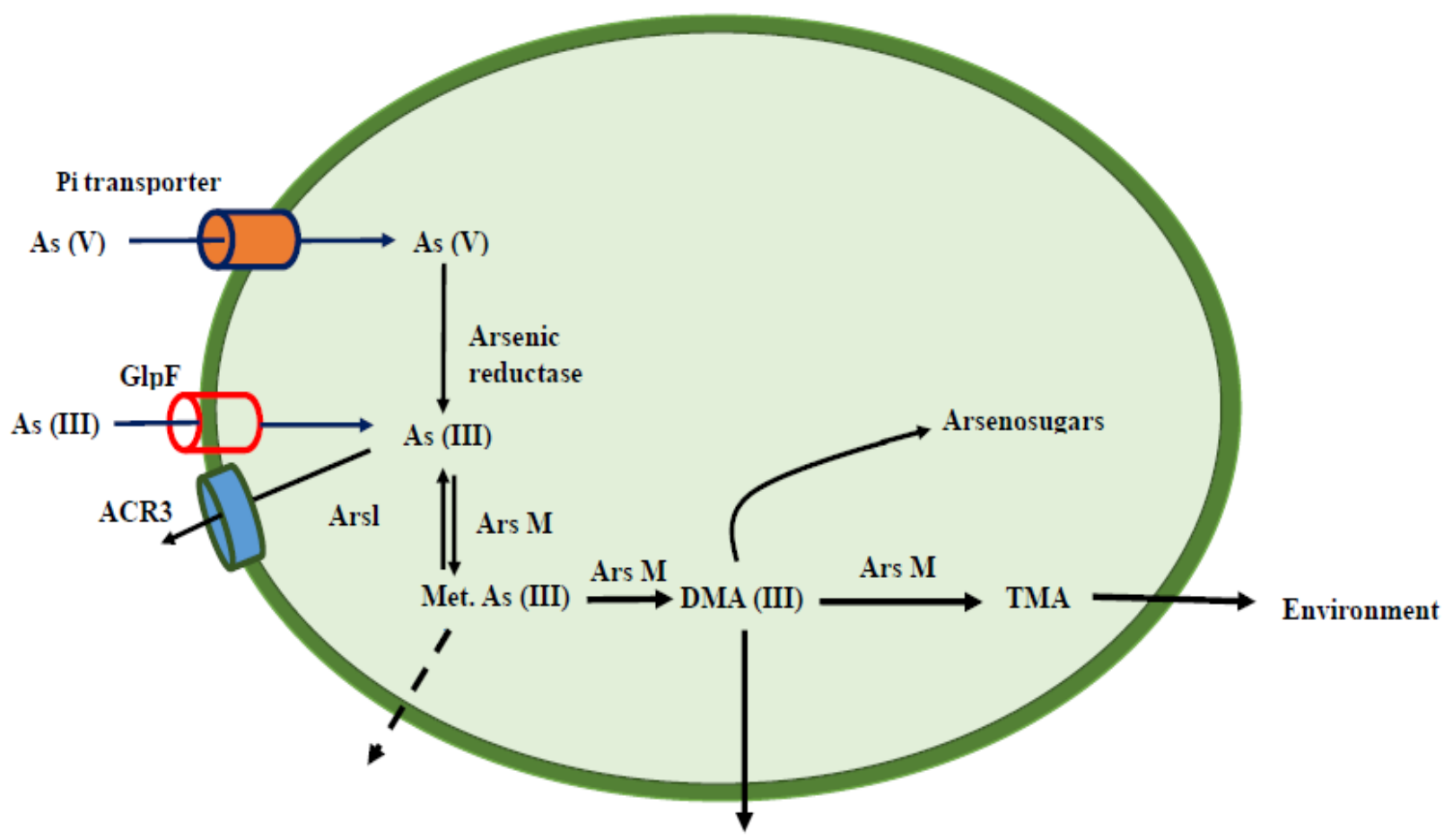

Fig. 5. Mechanism of As-detoxification in Nostoc

Medicago sativa and culture substances also noticed the remarkable up-regulation of RiMT11 gene in Rhizophagus irregularis.

All types of plant stresses generated reactive oxygen species (ROS) that cause oxidative stress, which disturbed intracellular activities such as oxidation of proteins, lipids peroxidation, and enzyme activity inhibition that cellular damage in the plant (Sharma et al., 2012). AM fungi upgraded and enhanced the antioxidant defense system like isoprenoid production, higher hydraulic conductivity, increased antioxidant production by increased ' $P$ ' uptake, glomalin protein production, improving osmotic adjustment and modification in growth and physiological of host plants (Rapparini et al., 2008; Wu and Zau, 2009; Evelin et al., 2009). AM fungi also help in the decontamination of metal-polluted soils and their broad application practicing in phytoremediation (Vallino et al., 2006; Bhargava et al., 2012; Meier et al., 2012). AM fungi check or slow the translocation of heavy metals from soil to root and reduce to reach in above-ground parts (Wu et al., 2015), thereby improving the plant health so food quality and safety are constant (Xie et al., 2015). The phosphatesolubilizing microbes affect the As-uptake and mitigate the stress through the process of precipitation, complexation, redox reactions, and nutrient availability (Rahman et al., 2015). Biosorption, exclusion, binding to cysteine-rich peptides/proteins, methylation, and volatilization, etc., were different mechanisms involved in the As-transformation (Upadhyay et al., 2018).

\section{Metallophytes as As-remediator}

[As] phytoremediation comprises different mechanisms which make plant tolerant against As stress such as accumulation, phytostabilization, phytoextraction, and phytovolatilization (Barbafieri et al., 2013; Favas et al., 2014). Metallophytes release root exudates which stimulate microbial activity and convert As into complex immobilizing forms through several chemical reactions such as acidification, chelation, complexation, precipitation, and redox reactions (Wuana and Okieimen, 2011; Bolan et al., 2011). As- hyperaccumulator plants accumulate As in different plant parts and also convenient means of As mitigation from soil (Fig. 4). The highest amount of As accumulated in Pteris vittata $(22,630 \mathrm{mg} /$ $\mathrm{kg}$ ) followed by Pityrogramma calomelanos $(8350 \mathrm{\mu g} /$ g) (Ma et al., 2001; Francesconi et al., 2002; Fitz et al., 2003). In the process of As-phytoremediation, plants generate gaseous arsine species also and released into the environment.

In-plant, intake of As via phosphate and aquaporin transport channel enzyme arsenic reductase which helps in conversion of As (V) and As (III) and converted As (III) stored in the vacuole(Ma et al., 2008; Wu and Okieimen, 2011). Yamaji and Ma (2011) reported Lsi 2 transporter responsible for inner translocation from the root cell to the xylem. The As reduction is governed by some functional genes in metallophytes. Nahar et al. (2017) investigated the role of cloned At ACR2 gene (arsenic reductase 2) As reduction in Arabidopsis thaliana. As reaches in different plant parts via vascular 
translocation through xylem cells and stabilized or volatilized in presence of As (III)-S-adenocylmethionine methyltransferase (arsM) (Qin et al., 2006). Pigna et al. (2010) investigated the role of phosphorus in detoxification and As uptake and their distribution in the root, shoot, and grain when wheat grown in As-polluted soil and concluded that enhanced phosphorus reduced As toxicity in the plant.

Sharma et al. (2017) experimented with the Triticum aestivum plant noticed the role of AM fungi amendment in artificially As contaminated medium with different doses. Their study revealed that AM fungi reduced oxidative stresses significantly and reduced As translocation from root to grains. AM fungi also increase different physiological, biochemical, and antioxidant enzymes in wheat. Soto et al. (2019) investigated the role of isolated two As-resistant bacteria (Psedomonas gessardii and Brevundimonas intermedia) and two fungi (Fimetariella rabenhorttii and Hormonema viticola) in the alleviation of As toxicity in $T$. aestivum and noticed that $P$. gessardii and Brevundimonas intermedia inoculation increased plant growth and also recorded overexpression of antioxidant synthase gene in plants. Ghorban et al. (2021) evaluated the inoculation effect of Piriformospora indica in As-stressed Oryza sativa, and found their positive role in restoring the photosynthetic pigments as well as tolerance by the downregulating Lsi2 expression and up- regulation of $\mathrm{PC}_{\mathrm{s}} 1$ and $\mathrm{PC}_{\mathrm{s}} 2$ protein expressions.

\section{Algae as As-remediator}

Algae developed multiple detoxifying mechanisms that involved redox potential, methylation, and demethylation etc. In algae, both methylation and demethylation processes coexist, but the reason for this coexistence and their metabolisms are unknown (Yan et al., 2017). Some marine alga contains As in their hydrocarbon chains in cellular bodies (García-Salgado et al., 2012). Nostoc showed the ability to methylation and demethylation of As with help of enzyme the S- adenosylmethionine methyltransferase (Ars M) (Yin et al., 2011) whereas, Ars I worked reverse to process (demethylation) (Yan et al., 2015). Methylated As (III) bound to Ars M and further converted to DMA (III) and TMA (III) (Yin et al., 2011). Xue et al. (2017) postulated and described arsenosugar phospholipid biosynthesis in Nostoc. In this process, S-adenosyl- L-methionine (SAM) provides methyl group to As (III) to generate TMA (III) with help of S- adenosylmethionine methyltransferase enzyme and further provides adenosyl group to DMA (III) for generating the basis of arsenosugar. The DMA synthesis (dimethyl arsinyladenasine) undergoes glycosidation to produce Oxo-arsenosugarglycerol (Oxo-Gly), which acts as the precursor of arsenosugar phosphides. Details of enzymes involved in arsenosugar synthesis are not yet identified as well.
Murray et al. (2003) identified arsenosugars in Chlorella vulgaris there are some other algal species viz., C. vulgaris, C. reinhardtii, Synechacystis sp. known for arsenosugar production. Xue et al. (2017) treated Nostoc sp. with arsenite As (III) for fourteen days and separated monomethylarsonate, dimethylarsonate, a glycerol arsenosugar (Oxo-Gly) and a phosphate arsenosugar $\left(\mathrm{Oxo}-\mathrm{PO}_{4}\right)$. These microalgae are applicable in As contaminated paddy crops. Paddy fields are suitable for algal growth and microbial activity helps As detoxification. The detailed mechanism of As detoxification by Nostoc is given in Fig. 5.

\section{Protozoa as As-remediator}

Protozoans are sensitive to toxic material and environmental pollutants. These characteristics make them ideal for use as experimental test organisms in ecological investigations (Yin et al., 2011). Yin et al. (2011) reported that Tetrahymena thermophile SB-210 accumulates 187 $\mathrm{mg} / \mathrm{kg}$ dry weight when it is exposed to $40 \mu \mathrm{M}$ with As (V) methylated species (MMA, TMA), accounting for $66 \%$ of the total amended As. In natural conditions, Euglena mutabilis tolerated up to $260 \mathrm{mg} / \mathrm{l}$ of As in medium (Squibb and Fowler, 1983). Casiotet al. (2004) studied E. mutabilis in severely loaded sulphate (1.9-4.9 g/l), iron (0.7-1.7 $\mathrm{g} / \mathrm{l})$, As (0.08-0.26 $\mathrm{g} / \mathrm{l})$ environments and found able to oxidized As (III) to As (V) but no substantial methylated As species were noticed. Yin et al. (2017) reported Tetrahymena pyriformis As biotransformation abilities in response to various ' $P$ ' and As concentrations. When exposed to As (V) for twenty hours and at low ' $P$ ' concentrations (3.6 and $15 \mathrm{mg} / \mathrm{l})$, As demonstrated dominance, whereas methylated forms such as MMA, DMA, and volatile As species showed a positive connection with initial 'P' concentrations.

\section{Conclusion}

As contamination in terrestrial and aquatic ecosystems is a very sensitive environmental issue due to its adverse impact on human health. It enters into the terrestrial and aquatic ecosystems through several natural processes such as weathering reactions, biological activity, volcanic emissions, and anthropogenic activities. The natural soil is a heaven of microbial diversity. In Agriculture, soil microbes are intimately associated with plant health and their production. The soil microbes have the potential for remediation of such soils. Biological remediation may play a great role to cope up with such pollutants. Soil microorganisms are responsible for the dynamics of the transformation and development of soil structure. Metal tolerant bacteria, saprophytic and mycorrhizal fungi have recently received great attention for establishing vegetation in heavy metal contaminated soils. These microbes have developed several mechanisms for the detoxification of heavy 
metals. The exploration of microbes for sustainable agriculture and the improvement of degrading habitats is a new approach to modern steps. The work on utilization of the microbes in their best way isalso needed to understand better their mechanisms, physiology, molecular and genomic details for the potential application at a large scale. In natural degrading habitats, microbes develop multiple mechanisms to cope up with such stresses. These mechanisms made of microbes can serve as bioremediation tools that transform toxins into less toxic substances. Some microbes volatilize As added in the environment (dilution effect) and the association of such potent microbes may help in bioremediation. On the other hand, some microbes are utilized as bio-barrier of As when it is amended with phosphorus. Thus, these studies suggest that microbes could be safely used to manage As contaminated areas.

\section{ACKNOWLEDGEMENTS}

The Dheeraj Pandey is thankful to University Grant Commission (UGC), New Delhi, for carrying out this study. The authors are also grateful to the Head of Botany Department, University of Allahabad, for providing laboratory and library facilities.

\section{Conflict of interest}

The authors declare that they have no conflict of interest.

\section{REFERENCES}

1. Abedin, M. J., Cotter-Howells, J. \& Meharg, A. A. (2002a) Arsenic uptake and accumulation in rice (Oryza sativa L.) irrigated with contaminated water. Plant Soil, 240(2), 311319.

2. Abedin, M. J., Cresser, M. S., Meharg, A. A., Feldmann, J. \& Cotter-Howells, J. (2002b). Arsenic accumulation and metabolism in rice (Oryza sativa L.). Environ. Sci. Technol. 36(5), 962-968.

3. Acharyya, S. K. \& Shah, B. A. (2007). Groundwater arsenic contamination affecting different geologic domains in India-a review: influence of geological setting, fluvial geomorphology and Quaternary stratigraphy. J. Environ. Sci. Health C, Part A, 42(12), 1795-1805.

4. Ahn, J. S. (2012). Geochemical occurrences of arsenic and fluoride in bedrock groundwater: a case study in $\mathrm{Ge}$ umsan County, Korea. Environ. Geochem. Health. 34(1), 43-54.

5. Alam, M. Z., Hoque, M. A., Ahammed, G. J. \& CarpenterBoggs, L.. (2020). Effects of arbuscular mycorrhizal fungi, biochar, selenium, silica gel, and sulfur on arsenic uptake and biomass growth in Pisum sativum L. Emerg. Contam. 6, 312-322.

6. Ali, W., Mushtaq, N., Javed, T., Zhang, H., Ali, K., Rasool, A. \& Farooqi, A. (2019). Vertical mixing with return irrigation water the cause of arsenic enrichment in groundwater of district Larkana Sindh, Pakistan. Environ. Pollut. 245,

\section{7-88.}

7. Anguita, J. M., Rojas, C., Pastén, P. A. \& Vargas, I. T. (2018). A new aerobic chemolithoautotrophic arsenic oxidizing microorganism isolated from a high Andean watershed. Biodegradation. 29(1), 59-69.

8. Anyanwu, C. U. \& Ugwu, C. E. (2010). Incidence of arsenic resistant bacteria isolated from a sewage treatment plant. Int. Res. J. Basic Appl. Sci.,10, 64-78.

9. Bagade, A., Nandre, V., Paul, D., Patil, Y., Sharma, N., Giri, A. \& Kodam, K. (2020). Characterisation of hyper tolerant Bacillus firmus L-148 for arsenic oxidation. Environ. Pollut., 261, 114124.

10. Barbafieri, M., Japenga, J., Romkens, P., Petruzzelli, G. \& Pedron, F. (2013). Protocols for applying phytotechnologies in metal-contaminated soils. In: Plant-based remediation processes, Springer Berlin Heidelberg, 19-37.

11. Bates, M. N., Smith, A. H. \& Hopenhayn-Rich, C. (1992). Arsenic ingestion and internal cancers: a review. Am. J. Epidemol., 135(5), 462-476.

12. Bayard, R., Chatain, V., Gachet, C., Troadec, A. \& Gourdon, R. (2006). Mobilisation of arsenic from a mining soil in batch slurry experiments under bio-oxidative conditions. Water Res., 40(6), 1240-1248.

13. Bhargava, A., Carmona, F.F., Bhargava, M. \& Srivastava, S. (2012). Approaches for enhanced phytoextraction of heavy metals. J. Environ. Manage., 105, 103-120.

14. Bhattacharya, P., Claesson, M., Bundschuh, J., Sracek, O., Fagerberg, J., Jacks, G. \& Thir, J. M. (2006). Distribution and mobility of arsenic in the Rio Dulce alluvial aquifers in Santiago del Estero Province, Argentina. Sci. Total Environ., 358(1-3), 97-120.

15. Bhattacharya, P., Welch, A. H., Stollenwerk, K. G., McLaughlin, M. J., Bundschuh, J. \& Panaullah, G.(2007). Arsenic in the environment: biology and chemistry. Sci. Total Environ., 1, 379(2-3),109-20.

16. Bogo, A. \& Mantle, P. G. (2000). Caffeine: also a fungal metabolite. Phytochemistry, 54(8), 937-939.

17. Bolan, N. S., Park, J. H., Robinson, B., Naidu, R. \& Huh, K.Y. (2011). Phytostabilization: a green approach to contaminant containment. Adv. Aron. 112, pp145-204.

18. Borgono, J. M. \& Greiber, R. (1971). Epidemiologic study of arsenic poisoning in the city of Antofagasta. Revista Medica de Chile, 99(9), 702-707.

19. Bravo, A., Brands, M., Wewer, V., Dörmann, P. \& Harrison, M.J. (2017). Arbuscular mycorrhiza $\square$ specific enzymes FatM and RAM 2 fine-tune lipid biosynthesis to promote development of arbuscular mycorrhiza. New Phytol., 214(4), 1631-1645.

20. Brundrett, M.C. \& Tedersoo, L. (2018). Evolutionary history of mycorrhizal symbioses and global host plant diversity. New Phytol. 220(4), 1108-1115.

21. Bundschuh, M., Zubrod, J.P., Kosol, S., Maltby, L., Stang, C., Duester, L. \& Schulz, R. (2011). Fungal composition on leaves explains pollutant-mediated indirect effects on amphipod feeding. Aqua. Toxicol., 104(1-2), pp.32-37.

22. Button, M., Koch, I., Watts, M. J. \& Reimer, K. J. (2020). Arsenic speciation in the bracket fungus Fomitopsis betulina from contaminated and pristine sites. Environ Geochem Health. 42(9), pp.2723-2732.

23. Cantamessa, S., Massa, N., Gamalero, E. \& Berta, G. (2020). Phytoremediation of a Highly Arsenic Polluted Site, Using Pteris vittata L. and Arbuscular Mycorrhizal 
Fungi. Plants, 9(9), p.1211.

24. Caporale, A. G., Sommella, A., Lorito, M., Lombardi, N., Azam, S. M., Pigna, M. \& Ruocco, M. (2014). Trichoderma spp. alleviate phytotoxicity in lettuce plants (Lactuca sativa L.) irrigated with arsenic-contaminated water. J. Plant Physiol., 171(15), 1378-1384.

25. Casiot, C., Bruneel, O., Personné, J. C., Leblanc, M.\& Elbaz-Poulichet, F. (2004). Arsenic oxidation and bioaccumulation by the acidophilic protozoan, Euglena mutabilis, in acid mine drainage (Carnoules, France). Sci. Total Environ. 320(2-3), 259-267.

26. Catarecha, P., Segura, M.D., Franco-Zorrilla, J.M., GarcíaPonce, B., Lanza, M., Solano, R. \& Leyva, A. (2007). A mutant of the Arabidopsis phosphate transporter PHT1; 1 displays enhanced arsenic accumulation. The Plant Cell, 19(3), 1123-1133.

27. Cath, T.Y., Childress, A.E. \& Elimelech, M. (2006). Forward osmosis: principles, applications, and recent developments. J. Memb. Sci. 281(1-2), 70-87.

28. Čerňanský, S., Kolenčík, M., Ševc, J., Urík, M.\& Hiller, E. (2009). Fungal volatilization of trivalent and pentavalent arsenic under laboratory conditions. Biores. Technol. 100 (2), 1037-1040.

29. Chandrajith, R., Diyabalanage, S. \& Dissanayake, C.B. (2020). Geogenic fluoride and arsenic in groundwater of Sri Lanka and its implications to community health. Groundwater Sust. Develop. 10, 100359.

30. Chen, B., Xiao, X., Zhu, Y.G., Smith, F.A., Xie, Z.M. \& Smith, S.E. (2007). The arbuscular mycorrhizal fungus Glomus mosseae gives contradictory effects on phosphorus and arsenic acquisition by Medicago sativa L. Sci. Total Environ. 379(2-3), 226-234.

31. Chen, G.Q., Zhu, J., Shi, X.G., Ni, J.H., Zhong, H.J., Si, G.Y., Jin, X.L., Tang, W., Li, X.S., Xong, S.M. \& Shen, Z.X. (1996). In vitro studies on cellular and molecular mechanisms of arsenic trioxide $\left(\mathrm{As}_{2} \mathrm{O}_{3}\right)$ in the treatment of acute promyelocytic leukemia: $\mathrm{As}_{2} \mathrm{O}_{3}$ induces NB4 cell apoptosis with down-regulation of $\mathrm{Bcl}-2$ expression and modulation of PML-RARa/PML proteins. Blood, 88(3), 1052-1061.

32. Chen, J., Qin, J., Zhu, Y.G., de Lorenzo, V. \& Rosen, B.P. (2013). Engineering the soil bacterium Pseudomonas putida for arsenic methylation. Appl. Environ. Microbiol., 79(14), 4493-4495.

33. Chen, J., Sun, G.X., Wang, X.X., Lorenzo, V.D., Rosen, B.P. \& Zhu, Y.G. (2014). Volatilization of arsenic from polluted soil by Pseudomonas putida engineered for expression of the arsM arsenic (III) S-adenosine methyltransferase gene. Environ. Sci. Techol.48(17), 10337-10344.

34. Chen, P., Li, J., Wang, H.Y., Zheng, R.L. \& Sun, G.J. (2017). Evaluation of bioaugmentation and biostimulation on arsenic remediation in soil through biovolatilization. Environ. Sci. Pollu. Res., 24(27), 21739-21749.

35. Christophersen, H.M., Smith, F. A. \& Smith, S.E. (2012). Unraveling the influence of arbuscular mycorrhizal colonization on arsenic tolerance in Medicago: Glomus mosseae is more effective than $G$. intraradices, associated with lower expression of root epidermal $\mathrm{Pi}$ transporter genes. Front. Physiol. 3, 91.

36. Clemmensen, K.E., Bahr, A., Ovaskainen, O., Dahlberg, A., Ekblad, A., Wallander, H. \& Lindahl, B.D. (2013). Roots and associated fungi drive long-term carbon sequestration in boreal forest. Science, 339(6127), 1615-1618.

37. Cozzolino, V., Pigna, M., Di Meo, V., Caporale, A.G. \& Violante, A. (2010). Effects of arbuscular mycorrhizal inoculation and phosphorus supply on the growth of Lactuca sativa $\mathrm{L}$. and arsenic and phosphorus availability in an arsenic polluted soil under non-sterile conditions. Appl. soil Ecol. 45(3), 262-268.

38. Das, T.K. (2019). Arsenic menace in West Bengal (India) and its mitigation through toolbox intervention: an experience to share. In Ground Water Development-Issues and Sustainable Solutions, Springer, Singapore. pp. 305-314.

39. Diao, M., Nguyen, T.A., Taran, E., Mahler, S.M. \& Nguyen, A.V. (2015). Effect of energy source, salt concentration and loading force on colloidal interactions between Acidithiobacillus ferrooxidans cells and mineral surfaces. Colloids Surf. B. 132, pp.271-280.

40. Edvantoro, B. B., Naidu, R., Megharaj, M., Merrington, G. \& Singleton, I. (2004). Microbial formation of volatile arsenic in cattle dip site soils contaminated with arsenic and DDT. Appl. Soil Ecol. 25(3), 207-217.

41. Evelin, H., Kapoor, R. \& Giri, B. (2009). Arbuscular mycorrhizal fungi in alleviation of salt stress: a review. Ann. Bot. 104(7), 1263-1280.

42. Farkas, B., Kolenčík, M., Hain, M., Dobročka, E., Kratošová, G., Bujdoš, M., Feng, H., Deng, Y., Yu, Q., Illa, R. \& Sunil, B.R. (2020). Aspergillus niger decreases bioavailability of Arsenic (V) via biotransformation of manganese oxide into biogenic oxalate minerals. J. Fungus. 6(4), p.270.

43. Favas, P.J., Pratas, J., Varun, M., D'Souza, R. \& Paul, M.S. (2014). Phytoremediation of soils contaminated with metals and metalloids at mining areas: potential of native flora. Environ. Risk Assess. Soil Contam., 3, 485-516.

44. Feldman, P.R., Rosenboom, J. W., Saray, M., Samnang, C., Navuth, P. \& Iddings, S. (2007). Assessment of the chemical quality of drinking water in Cambodia. J. Water Health, 5(1), 101-116.

45. Feng, Q., Su, S., Zeng, X., Zhang, Y., Li, L., Bai, L., Duan, R.\& Lin, Z. (2015). Arsenite resistance, accumulation, and volatilization properties of Trichoderma asperellum SM-12 F 1, Penicillium janthinellum SM-12 F 4, and Fusarium oxysporum CZ-8F1. CLEAN-Soil, Air, Water, 43(1), pp.141-146.

46. Figoli, A., Cassano, A., Criscuoli, A., Mozumder, M. S. I., Uddin, M. T., Islam, M. A. \& Drioli, E. (2010). Influence of operating parameters on the arsenic removal by nanofiltration. Water Res. 44(1), 97-104.

47. Fitz, W.J., Wenzel, W.W., Zhang, H., Nurmi, J., Štipek, K., Fischerova, Z., Schweiger, P., Köllensperger, G., Ma, L.Q. \& Stingeder, G. (2003). Rhizosphere characteristics of the arsenic hyperaccumulator Pteris vittata L. and monitoring of phyto removal efficiency. Environ. Sci. Techol.37(21), pp.5008-5014.

48. Fontaine, J.A. (1994). Regulating arsenic in Nevada drinking water supplies: past problems, future challenges. Expos. Health, 285-288.

49. Fordyce, F.M., Williams, T.M., Paijitprapapon, A. \& Charoenchaisri, P. (1995). Hydrogeochemistry of arsenic in an area of chronic mining-related arsenism, Ron Phibun district, Nakhon Si Thammarat Province, Thailand: preliminary results. 
Pandey, D. et al. / J. Appl. \& Nat. Sci. 13(4), 1499 - 1517 (2021)

50. Francesconi, K., Visoottiviseth, P., Sridokchan, W. \& Goessler, W. (2002). Arsenic species in an arsenic hyperaccumulating fern, Pityrogramma calomelanos: a potential phytoremediator of arsenic-contaminated soils. Sci. Total Environ., 284(1-3), 27-35.

51. García-Salgado, S., Raber, G., Raml, R., Magnes, C. \& Francesconi, K.A. (2012). Arsenosugar phospholipids and arsenic hydrocarbons in two species of brown macroalgae. Environ. Chem. 9(1), pp.63-66.

52. Garg, N. \& Singla, P. (2012). The role of Glomus mosseae on key physiological and biochemical parameters of pea plants grown in arsenic contaminated soil. Sci. hortic.,143, 92-101.

53. Gbadebo, A.M. (2005). Arsenic Pollution in aquifers located within limestone areas of Ogun state, Nigeria. In: Natural Arsenic in Groundwater: Occurrence, Remediation and Management, 85-92.

54. Göhre, V. \& Paszkowski, U. (2006). Contribution of the arbuscular mycorrhizal symbiosis to heavy metal phytoremediation. Planta, 223(6), 1115-1122.

55. González-Chávez, M. D. C. A., del Pilar Ortega-Larrocea, M., Carrillo-González, R., López-Meyer, M., XoconostleCázares, B., Gomez, S.K. \& Maldonado-Mendoza, I. E. (2011). Arsenate induces the expression of fungal genes involved in As transport in arbuscular mycorrhiza. Fungal Biol., 115(12), 1197-1209.

56. Govarthanan, M., Mythili, R., Kamala-Kannan, S., Selvankumar, T., Srinivasan, P. \& Kim, H. (2019). In-vitro biomineralization of arsenic and lead from aqueous solution and soil by wood rot fungus, Trichoderma sp. Ecotoxicol. Environ. Saf. 174, pp.699-705.

57. Green, H.H.(1918). Description of a bacterium which oxidizes arsenite to arsenate, and of one which reduces arsenate to arsenite, isolated from a cattle-dipping Etank. South Af. J. Sci., 14, 465-467.

58. Gupta, D.K., Srivastava, S., Huang, H.G., RomeroPuertas, M.C. \& Sandalio, L.M. (2011). Arsenic tolerance and detoxification mechanisms in plants. In Detoxification of Heavy Metals, Springer Berlin Heidelberg. 169-179.

59. Gupta, S., Thokchom, S.D. \& Kapoor, R. (2021). Arbuscular mycorrhiza improves photosynthesis and restores alteration in sugar metabolism in Triticum aestivum L. grown in arsenic contaminated soil. Front. Plant Sci., 12, 334.

60. Hijikata, N., Murase, M., Tani, C., Ohtomo, R., Osaki, M. \& Ezawa, T. (2010). Polyphosphate has a central role in the rapid and massive accumulation of phosphorus in extraradical mycelium of an arbuscular mycorrhizal fungus. New phytol. 186(2), 285-289.

61. Huang, J.H., Scherr, F. \& Matzner, E. (2007). Demethylation of dimethylarsinic acid and arsenobetaine in different organic soils. Water Air Soil Pollut., 182(1-4), 31-41.

62. Irshad, S., Xie, Z., Mehmood, S., Nawaz, A., Ditta, A. \& Mahmood, Q. (2021). Insights into conventional and recent technologies for arsenic bioremediation: A systematic review. Environ. Sci. Pollut. Res., 1-23.

63. Irshad, S., Xie, Z., Wang, J., Nawaz, A., Luo, Y., Wang, Y. \& Mehmood, S. (2020). Indigenous strain Bacillus XZM assisted phytoremediation and detoxification of arsenic in Vallisneria denseserrulata. J. Hazard. Mater. 381, p.120903.

64. Jankong, P. \& Visoottiviseth, P. (2008). Effects of arbuscular mycorrhizal inoculation on plants growing on arsenic contaminated soil. Chemosphere, 72(7), 1092-1097.

65. Jebeli, M.A., Maleki, A., Amoozegar, M.A., Kalantar, E., Izanloo, H. \& Gharibi, F. (2017). Bacillus flexus strain As12, a new arsenic transformer bacterium isolated from contaminated water resources. Chemosphere, 169, pp. 636-641.

66. Jia, Y., Huang, H., Zhong, M., Wang, F. H., Zhang, L. M. \& Zhu, Y. G. (2013). Microbial arsenic methylation in soil and rice rhizosphere. Environ. Sci. Techol., 47(7), 31413148.

67. Jiang, Y., Wang, W., Xie, Q., Liu, N., Liu, L., Wang, D. \& Wang, E. (2017). Plants transfer lipids to sustain colonization by mutualistic mycorrhizal and parasitic fungi. Science, 356(6343), 1172-1175.

68. Khan, A.G. (2005). Role of soil microbes in the rhizospheres of plants growing on trace metal contaminated soils in phytoremediation. J. Trace Ele. Med. Biol. 18(4), 355-364.

69. Kuehnelt, D. \& Goessler, W. (2003). Organoarsenic compounds in the terrestrial environment. Organometallic Comp. Environ., 223-275.

70. Latef, A.A. (2011). Influence of arbuscular mycorrhizal fungi and copper on growth, accumulation of osmolyte, mineral nutrition and antioxidant enzyme activity of pepper (Capsicum annuum L.). Mycorrhiza, 21(6), 495-503.

71. Lazo-Langner, A., Goss, G.D., Spaans, J.N. \& Rodger, M.A. (2007). The effect of low-molecular-weight heparin on cancer survival. A systematic review and meta-analysis of randomized trials. J. Thrombosis Haemostasis, 5(4), 729-737.

72. Lee, E., Han, Y., Park, J., Hong, J., Silva, R.A., Kim, S. \& $\mathrm{Kim}, \mathrm{H}$. (2015). Bioleaching of arsenic from highly contaminated mine tailings using Acidithiobacillus thiooxidans. $J$ Environ Manage., 147, 124-131.

73. Lee, Y., Um, I.H.\& Yoon, J. (2003). Arsenic (III) oxidation by iron (VI) (ferrate) and subsequent removal of arsenic (V) by iron (III) coagulation. Environ. Sci. Techol., 37(24), 5750-5756.

74. Le Luu, T. (2019). Remarks on the current quality of groundwater in Vietnam. Environ. Sci. Pollut. Res., 26(2), 1163-1169.

75. Leng, F., Sun, S., Wang, Y., Jing, Y., Wei, Q. \& Li, H. (2016). Arsenic bioleaching in medical realgar ore and arsenicbearing refractory gold ore by combination of Acidithiobacillus ferrooxidans and Acidithiobacillus thiooxidans. Trop. J. of Pharm. Res., 15(5), 1031-1038.

76. Lenoir, I., Fontaine, J. \& Sahraoui, A.L.(2016). Arbuscular mycorrhizal fungal responses to abiotic stresses: a review. Phytochemistry, 123, 4-15.

77. Li, J., Chen, B., Zhang, X., Hao, Z., Zhang, X. \& Zhu, Y. (2021). Arsenic transformation and volatilization by arbuscular mycorrhizal symbiosis under axenic conditions. $J$. Hazard. Mater. 413, 125390.

78. Lin, Y.F., Yang, J. \& Rosen, B.P. (2007). ArsD: an As (III) metallochaperone for the ArsAB As (III)-translocating ATPase. J. Bioenerg. Biomembr., 39(5-6), 453-458.

79. Liu, W.J., Zhu, Y.G., Smith, F.A. \& Smith, S.E.(2004). Do iron plaque and genotypes affect arsenate uptake and translocation by rice seedlings (Oryza sativa L.) grown in solution culture? J. Exp. Bot. 55(403), 1707-1713.

80. Liu, Y., Zhu, Y.G., Chen, B.D., Christie, P. \& Li, X. L. (2005). Influence of the arbuscular mycorrhizal fungus 
Glomus mosseae on uptake of arsenate by the As hyperaccumulator fern Pteris vittata L. Mycorrhiza, 15(3), 187192.

81. Liu, C. W. \& Wu, M. Z. (2019). Geochemical, mineralogical and statistical characteristics of arsenic in groundwater of the Lanyang Plain, Taiwan. J. Hydrol., 577, 123975.

82. Loukidou, M.X., Matis, K.A., Zouboulis, A.I.\& LiakopoulouKyriakidou, M. (2003). Removal of As (V) from wastewaters by chemically modified fungal biomass. Water Res., 37(18), 4544-4552.

83. Ma, J. F., Yamaji, N., Mitani, N., Xu, X.Y., Su, Y.H., McGrath, S.P. \& Zhao, F.J. (2008). Transporters of arsenite in rice and their role in arsenic accumulation in rice grain. Proc. Nat. Acad. Sci., 105(29), 9931-9935.

84. Ma, L.Q., Komar, K.M., Tu, C., Zhang, W., Cai, Y. \& Kennelley, E.D. (2001). A fern that hyperaccumulates arsenic. Nature, 409(6820), 579.

85. Macur, R.E., Wheeler, J.T., McDermott, T.R. \& Inskeep, W.P. (2001). Microbial populations associated with the reduction and enhanced mobilization of arsenic in mine tailings. Environ. Sci. Techol., 35(18), 3676-3682.

86. Maldonado-Mendoza, I. E. \& Harrison, M. J. (2018). RiArsB and RiMT-11: Two novel genes induced by arsenate in arbuscular mycorrhiza. Fungal Biol. 122(2-3), 121-130.

87. Mallick, I., Bhattacharyya, C., Mukherji, S., Dey, D. Sarkar, S.C., Mukhopadhyay, U.K. \& Ghosh, A. (2018). Effective rhizoinoculation and biofilm formation by arsenic immobilizing halophilic plant growth promoting bacteria (PGPB) isolated from mangrove rhizosphere: a step towards arsenic rhizoremediation. Sci. Total Environ., 610, 1239-1250

88. Mandal, B.K. \& Suzuki, K.T. (2002). Arsenic round the world: a review. Talanta, 58(1), 201-235.

89. Martínez-Villegas, N., Briones-Gallardo, R., Ramos-Leal, J.A., Avalos-Borja, M., Castañón-Sandoval, A.D., RazoFlores, E. \& Villalobos, M. (2013). Arsenic mobility controlled by solid calcium arsenates: A case study in Mexico showcasing a potentially widespread environmental problem. Environ. Pollut., 176, 114-122.

90. Mass, M.J., Tennant, A., Roop, B.C., Cullen, W.R., Styblo, M., Thomas, D.J. \& Kligerman, A.D. (2001). Methylated trivalent arsenic species are genotoxic. Chem. Res. Toxicol. 14(4), 355-361.

91. Matschullat, J. (2000). Arsenic in the geosphere-a review. Sci. Total Environ., 249(1-3), 297-312.

92. Mazumder, D.G. (2005). Effect of chronic intake of arsenic -contaminated water on liver. Toxicol. Appl. Pharmacol. 206(2), 169-175.

93. Medunić, G., Fiket, Ž. \& Ivanić, M. (2020). Arsenic contamination status in Europe, Australia, and other parts of the world. In Arsenic in Drinking Water and Food. Springer, Singapore, pp. 183-233.

94. Meier, S., Borie, F., Bolan, N. \& Cornejo, P. (2012). Phytoremediation of metal-polluted soils by arbuscular mycorrhizal fungi. Crit. Rev. Environ. Sci. Technol. 42(7), 741775 .

95. Mohd, S., Kushwaha, A.S., Shukla, J., Mandrah, K., Shankar, J., Arjaria, N., Saxena, P.N., Khare, P., Narayan, R., Dixit, S. \& Siddiqui, M.H. (2019). Fungal mediated biotransformation reduces toxicity of arsenic to soil dwelling microorganism and plant. Ecotoxicol. Environ. Saf. 176, pp.108-118.
96. Mondal, P., Bhowmick, S., Chatterjee, D., Figoli, A. \& Van der Bruggen, B. (2013). Remediation of inorganic arsenic in groundwater for safe water supply: a critical assessment of technological solutions. Chemosphere, 92(2), 157 -170 .

97. Mujawar, S.Y., Vaigankar, D.C. \& Dubey, S.K. (2021). Biological characterization of Bacillus flexus strain SSAI1 transforming highly toxic arsenite to less toxic arsenate mediated by periplasmic arsenite oxidase enzyme encoded by aioAB genes. BioMetals, pp.1-13.

98. Mukherjee, A., Gupta, S., Coomar, P., Fryar, A.E., Guillot, S., Verma, S. \& Charlet, L.(2019). Plate tectonics influence on geogenic arsenic cycling: From primary sources to global groundwater enrichment. Sci. Total Environ.683, 793-807.

99. Mukhopadhyay, R., Rosen, B.P., Phung, L.T. \& Silver, S. (2002). Microbial arsenic: from geocycles to genes and enzymes. FEMS Microbiol. Rev. 26(3), 311-325.

100.Mendoza-Chávez, C.E., Carabin, A., Dirany, A., Drogui, P., Buelna, G., Meza-Montenegro, M.M., Ulloa-Mercado, R.G., Diaz-Tenorio, L.M., Leyva-Soto, L.A. \& GortáresMoroyoqui, P. (2020). Statistical optimization of arsenic removal from synthetic water by electrocoagulation system and its application with real arsenic-polluted groundwater. Environ. technol. 1-12.

101.Murray, L.A., Raab, A., Marr, I.L. \& Feldmann, J. (2003). Biotransformation of arsenate to arsenosugars by Chlorella vulgaris. Appl. Organometal. Chem. 17(9), 669-674.

102.Mushtaq, T., Shah, A.A., Akram, W. \& Yasin, N.A. (2020). Synergistic ameliorative effect of iron oxide nanoparticles and Bacillus subtilis S4 against arsenic toxicity in Cucurbita moschata: polyamines, antioxidants, and physiochemical studies. Int. J. Phytoremediation., 22(13), pp. 1408-1419.

103. National Research Council (US). (1980). Committee on the Biological Effects of lonizing Radiations, \& United States. Environmental Protection Agency. Office of Radiation Programs. The Effects on Populations of Exposure to Low Levels of Ionizing Radiation, National Academy Press, 3095.

104.Nelson, K.W. (1977). Industrial contributions of arsenic to the environment. Environ. Health Persp., 19, 31-34.

105.Nguyen, T.H., Tran, H.N., Vu, H.A., Trinh, M.V., Nguyen, T.V., Loganathan, P., Vigneswaran, S., Nguyen, T.M., Vu, D.L. \& Nguyen, T.H.H. (2020). Laterite as a low-cost adsorbent in a sustainable decentralized filtration system to remove arsenic from groundwater in Vietnam. Sci.Total Environ. 699,134267

106.Nottingham, A.T., Turner, B.L., Winter, K., van der Heijden, M.G. \& Tanner, E.V. (2010). Arbuscular mycorrhizal mycelial respiration in a moist tropical forest. New Phytol. 186(4), 957-967.

107. Oremland, R.S. \& Stolz, J.F.(2003). The ecology of arsenic. Science. 300(5621), 939-944.

108. Oyarzun, R., Lillo, J., Higueras, P., Oyarzún, J., Maturana, $H$. (2004). Strong arsenic enrichment in sediments from the Elqui watershed, Northern Chile: industrial (gold mining at El Indio-Tambo district) vs. geologic processes. J. Geochem. Explor., 84(2), 53-64.

109.Pal, A. \& Paknikar, K.M. (2012). Bioremediation of arsenic from contaminated water. In: Microorganisms in Environmental Management, Springer, Dordrecht, pp. 477- 
Pandey, D. et al. / J. Appl. \& Nat. Sci. 13(4), 1499 - 1517 (2021)

523.

110.Pathare, V., Srivastava, S., Sonawane, B.V. \& Suprasanna, P. (2016). Arsenic stress affects the expression profile of genes of 14-3-3 proteins in the shoot of mycorrhiza colonized rice. Physiol. Mol. Biol. Plants, 22(4), 515-522.

111.Persson, B.L., Petersson, J., Fristedt, U., Weinander, R., Berhe, A. \& Pattison, J. (1999). Phosphate permeases of Saccharomyces cerevisiae: structure, function and regulation. Biochimica et Biophysica acta, 1422(3), 255-272.

112.Peters, G.P. (2008). From production-based to consumption-based national emission inventories. Ecol. Econ., 65 (1), 13-23.

113.Peters, R.W. (1999). Chelant extraction of heavy metals from contaminated soils. J. Hazard. Mater. 66(1-2), 151 210.

114.Pigna, M., Cozzolino, V., Giandonato Caporale, A., Mora, M.L., Di Meo, V., Jara, A.A. \& Violante, A. (2010). Effects of phosphorus fertilization on arsenic uptake by wheat grown in polluted soils. J. Soil Sci. Plant Nutr., 10(4), 428442.

115.Pokhrel, D. \& Viraraghavan, T. (2006). Arsenic removal from an aqueous solution by a modified fungal biomass. Water Res. 40(3), 549-552.

116.Qin, J., Rosen, B.P., Zhang, Y., Wang, G., Franke, S. \& Rensing, C. (2006). Arsenic detoxification and evolution of trimethylarsine gas by a microbial arsenite $\mathrm{S}$ adenosylmethionine methyltransferase. Proc. Nat. Acad. Sci. United States Am. 103(7), 2075-2080.

117.Rabbani, U., Mahar, G., Siddique, A. \& Fatmi, Z. (2017). Risk assessment for arsenic-contaminated groundwater along River Indus in Pakistan. Environ. Geochem., Health, 39(1), 179-190.

118.Rahman, A., Nahar, N., Nawani, N. N., Jass, J., Ghosh, S., Olsson, B. \& Mandal, A. (2015). Comparative genome analysis of Lysinibacillus B1-CDA, a bacterium that accumulates arsenics. Genomics, 106(6), 384-392.

119.

120.Ranjan, R., Kumar, N., Gautam, A., Dubey, A.K., Pandey, S.N. \& Mallick, S. (2021). Chlorella sp. modulates the glutathione mediated detoxification and $S$ adenosylmethionine dependent methyltransferase to counter arsenic toxicity in Oryza sativa L. Ecotoxicol. Environ. Saf. 208, p.111418.

121.Rapparini, F., Llusià, J. \& Peñuelas, J. (2008). Effect of arbuscular mycorrhizal (AM) colonization on terpene emission and content of Artemisia annua L. Plant Biol., 10(1), 108-122.

122. Ravenscroft, P., Brammer, H. \& Richards, K (2011). Arsenic pollution: a global synthesis, John Wiley \& Sons, 94.

123.Rodriguez-Freire, L., Moore, S.E., Sierra-Alvarez, R., Root, R.A., Chorover, J.\& Field, J.A. (2016). Arsenic remediation by formation of arsenic sulfide minerals in a continuous anaerobic bioreactor. Biotechnol. Bioeng. 113 (3), pp.522-530

124.Sánchez, Y., Amrán, D., Fernández, C., de Blas, E. \& Aller, P. (2008). Genistein selectively potentiates arsenic trioxide-induced apoptosis in human leukemia cells via reactive oxygen species generation and activation of reactive oxygen species-inducible protein kinases (p38-MAPK, AMPK). Int. J. Cancer, 123(5), 1205-1214.
125.Shalaby, A.M. (2003). Responses of arbuscular mycorrhizal fungal spores isolated from heavy metal-polluted and unpolluted soil to $\mathrm{Zn}, \mathrm{Cd}, \mathrm{Pb}$ and their interactions in vitro. Pakistan J. Biol. Sci. 6(16), 1416-1422.

126.Shaji, E., Santosh, M., Sarath, K.V., Prakash, P., Deepchand, V. \& Divya, B.V. (2021). Arsenic contamination of groundwater: A global synopsis with focus on the Indian Peninsula. Geosci. frontiers, 12(3), 101079.

127.Sharma, P., Jha, A. B., Dubey, R. S. \& Pessarakli, M. (2012). Reactive oxygen species, oxidative damage, and antioxidative defense mechanism in plants under stressful conditions. J. Bot. Article ID 217037.

128.Sharma, S., Anand, G., Singh, N. \& Kapoor, R. (2017). Arbuscular mycorrhiza augments arsenic tolerance in wheat (Triticum aestivum L.) by strengthening antioxidant defense system and thiol metabolism. Front. Plant Sci. 8, 906.

129.Sharma, V.K. (2007). Ferrate studies for disinfection and treatment of drinking water Advances in Control of Disinfection By-Products in Drinking Water Systems, 1-6

130.Sharma, V.K. \& Sohn, M. (2009). Aquatic arsenic: toxicity, speciation, transformations, and remediation. Environ. Int. 35(4), 743-759

131.Shen, Z.X., Chen, G.Q., Ni, J.H., Li, X.S., Xiong, S.M., Qiu, Q.Y., Zhu, J., Tang, W., Sun, G.L., Yang, K.Q. \& Chen, Y. (1997). Use of arsenic trioxide $\left(\mathrm{As}_{2} \mathrm{O}_{3}\right)$ in the treatment of acute promyelocytic leukemia (APL): II. Clinical efficacy and pharmacokinetics in relapsed patients. Blood J. Am. Soci. Hematol. 89(9), 3354-3360.

132.Sher, S., Sultan, S. \& Rehman, A. (2021). Characterization of multiple metal resistant Bacillus licheniformis and its potential use in arsenic contaminated industrial wastewater. Appl. Water Sci., 11(4), 1-7.

133.Sierra-Alvarez, R., Yenal, U., Field, J. A., Kopplin, M., Gandolfi, A.J. \& Garbarino, J. R.(2006). Anaerobic biotransformation of organo-arsenical pesticides monomethyl -arsonic acid and dimethyl-arsinic acid. J. Agri. Food Chem. 54(11), 3959-3966.

134.Silver, S. \& Phung, L.T. (2005). Genes and enzymes involved in bacterial oxidation and reduction of inorganic arsenic. Appl. Environ. Microbiol. 71(2), 599-608.

135.Singh, M., Srivastava, P.K., Verma, P.C., Kharwar, R.N., Singh, N. \& Tripathi, R.D. (2015). Soil fungi for mycoremediation of arsenic pollution in agriculture soils. J. Appl. Microbiol. 119(5), 1278-1290

136.Smedley, P.L. (1996). Arsenic in rural groundwater in Ghana: part special issue: hydrogeochemical studies in sub-Saharan Africa. J. Afri. Earth Sci., 22(4), 459-470.

137.Smedley, P.L. \& Kinniburgh, D.G. (2002). A review of the source, behaviour and distribution of arsenic in natural waters. Appl. Geochem., 17, 517-568.

138.Smith, E., Juhasz, A.L., Weber, J. \& Naidu, R. (2008). Arsenic uptake and speciation in rice plants grown under greenhouse conditions with arsenic contaminated irrigation water. Sci. Total Environ. 392(2-3), 277-283.

139.Smith, S.E.\& Read, D.J. (2008). Mycorrhizal symbiosis. 3rd. Academic Press New York, 605.

140.Soto, J., Ortiz, J., Herrera, H., Fuentes, A., Almonacid, L., Charles, T.C. \& Arriagada, C. (2019). Enhanced arsenic tolerance in Triticum aestivum inoculated with arsenicresistant and plant growth promoter microorganisms from 
a heavy metal-polluted soil. Microorganisms, 7(9), 348.

141.Spagnoletti, F.N., Balestrasse, K., Lavado, R.S. \& Giacometti, R. (2016). Arbuscular mycorrhiza detoxifying response against arsenic and pathogenic fungus in soybean. Ecotoxicol. Environ. Saf., 133, 47-56.

142.Squibb, K.S.\& Fowler, B.A. (1983). The toxicity of arsenic and its compounds. Biol. Environ. Effects Arsenic, 233.

143.Srivastava, P.K., Vaish, A., Dwivedi, S., Chakrabarty, D., Singh, N. \& Tripathi, R.D. (2011). Biological removal of arsenic pollution by soil fungi. Sci. Total Environ. 409 (12), 2430- 2442.

144.Srivastava, S., Suprasanna, P. \& D'souza, S.F. (2012). Mechanisms of arsenic tolerance and detoxification in plants and their application in transgenic technology: a critical appraisal. Int. J. Phytorem. 14(5), 506-517.

145.Stopelli, E., Duyen, V.T., Mai, T.T., Trang, P.T., Viet, P.H., Lightfoot, A., Kipfer, R., Schneider, M., Eiche, E., Kontny, A. \& Neumann, T. (2020). Spatial and temporal evolution of groundwater arsenic contamination in the Red River delta, Vietnam: Interplay of mobilisation and retardation processes. Sci. Total Environ. 717, 137143.

146.Stolz, J.F., Basu, P., Santini, J.M. \& Oremland, R.S. (2006). Arsenic and selenium in microbial metabolism. Ann. Rev. Microbiol. 60, 107-130.

147.Stroud, J.L., Norton, G.J., Islam, M.R., Dasgupta, T., White, R.P., Price, A.H. \& Zhao, F.J. (2011). The dynamics of arsenic in four paddy fields in the Bengal delta. Environ. Pollut. 159(4), 947-953.

148.Su, S.M., Zeng, X.B., Li, L.F., Duan, R, Bai, L. Y., Li, A.G. \& Jiang, S. (2012). Arsenate reduction and methylation in the cells of Trichoderma asperellum SM-12F1, Penicillium janthinellum SM-12F4, and Fusarium oxysporum CZ-8F1 investigated with X-ray absorption near edge structure. J. Hazard. Mater. 243, 364-367.

149.Sullivan, C., Tyrer, M., Cheeseman, C.R. \& Graham, N.J. (2010). Disposal of water treatment wastes containing arsenic- a review. Sci. Total Environ. 408(8), 17701778.

150.Sun, G., Yu, G., Zhao, L., Li, X., Xu, Y., Li, B. \&Sun, D. (2019). Endemic Arsenic Poisoning. In Endemic Disease in China, Springer, Singapore, pp. 97-123.

151.Tangahu, B.V., Sheikh Abdullah, S.R., Basri, H., Idris, M., Anuar, N. \& Mukhlisin, M. (2011). A review on heavy metals $(\mathrm{As}, \mathrm{Pb}$, and $\mathrm{Hg}$ ) uptake by plants through phytoremediation. Int. J. Chem. Engin. 2011.

152.Tani, Y., Miyata, N., Ohashi, M., Ohnuki, T., Seyama, H., Iwahori, K. \& Soma, M. (2004). Interaction of inorganic arsenic with biogenic manganese oxide produced by a Mn-oxidizing fungus, strain KR21-2. Environ. Sci. Technol. 38(24), 6618-6624.

153.Tapase, S.R. \& Kodam, K.M. (2018). Assessment of arsenic oxidation potential of Microvirga indica S-MI1b sp. nov. in heavy metal polluted environment. Chemosphere, 195, pp.1-10.

154.Tonin, C., Vandenkoornhuyse, P., Joner, E. J., Straczek, J. \& Leyval, C. (2001). Assessment of arbuscular mycorrhizal fungi diversity in the rhizosphere of Viola calaminaria and effect of these fungi on heavy metal uptake by clover. Mycorrhiza, 10(4), 161-168.

155.Tripathi, P., Singh, P.C., Mishra, A., Srivastava, S.,
Chauhan, R., Awasthi, S. \& Tripathi, R.D. (2017). Arsenic tolerant Trichoderma sp. reduces arsenic induced stress in chickpea (Cicer arietinum L.). Environ. Pollut. 223, 137145.

156.Tripathi, P., Tripathi, R.D., Singh, R.P., Dwivedi, S., Goutam, D., Shri, M. \& Chakrabarty, D. (2013). Silicon mediates arsenic tolerance in rice (Oryza sativa L.) through lowering of arsenic uptake and improved antioxidant defence system. Ecol. Engin., 52, 96-103.

157.Tripathi, R.D., Srivastava, S., Mishra, S., Singh, N., Tuli, R., Gupta, D.K. \& Maathuis, F.J. (2007). Arsenic hazards: strategies for tolerance and remediation by plants. Trends Biotechnol., 25(4), 158-165.

158.Tsai, S.L., Singh, S. \& Chen, W. (2009). Arsenic metabolism by microbes in nature and the impact on arsenic remediation. Curr. Opin. Biotechnol., 20(6), 659-667.

159.Tseng, C.H., Tai, T.Y., Chong, C.K., Tseng, C.P., Lai, M.S., Lin, B.J. \& Chen, C.J. (2000). Long-term arsenic exposure and incidence of non-insulin-dependent diabetes mellitus: a cohort study in arseniasis-hyperendemic villages in Taiwan. Environ. Health Persp., 108(9), 847851.

160.Uddin, R. \& Huda, N.H. (2011). Arsenic poisoning in Bangladesh. Oman Med. J. 26(3), 207.

161.Upadhyay, M.K., Yadav, P., Shukla, A. \& Srivastava, S. (2018). Utilizing the potential of microorganisms for managing arsenic contamination: a feasible and sustainable approach. Front. Environ. Sci. 6, 24.

162.Ure, A.M. \& Berrow, M.L. (1982). The elemental constituents of soils. In: Environmental chemistry 2. The Royal Society of Chemistry, London.

163.Urík, M., Farkas, B., Miglierini, M.B., Bujdoš, M., Mitróová, Z., Kim, H. \& Matúš, P., (2021). Mobilisation of hazardous elements from arsenic-rich mine drainage ochres by three Aspergillus species. J. Hazard. Mater., 409, p.124938.

164.Vallee, B.L., Ulmer, D.D. \& Wacker, W.E.C. (1960). Arsenic toxicology and biochemistry. J. Occup. Environ. Med. 2(7), p.358.

165.Vallino, M., Massa, N., Lumini, E., Bianciotto, V., Berta, G. \& Bonfante, P. (2006). Assessment of arbuscular mycorrhizal fungal diversity in roots of Solidago gigantea growing in a polluted soil in Northern Italy. Environ. Microbiol. 8(6), 971-983.

166. Vasudevan, S., Mohan, S., Sozhan, G., Raghavendran, N.S. \& Murugan, C.V.(2006). Studies on the oxidation of As (III) to As (V) by in-situ-generated hypochlorite. Indus. Engin. Chem. Res., 45(22), 7729-7732.

167.Villadangos, A.F., Van Belle, K., Wahni, K., Tamu Dufe, V., Freitas, S., Nur, H. \& Messens, J. (2011). Corynebacterium glutamicum survives arsenic stress with arsenate reductases coupled to two distinct redox mechanisms. Mol. Microbiol. 82(4), 998-1014.

168. Visoottiviseth, P. \& Panviroj, N. (2001). Selection of fungi capable of removing toxic arsenic compounds from liquid medium. Sci. Asia, 27, 83-92.

169.Waghunde, R.R., Shelake, R.M. \& Sabalpara, A.N. (2016). Trichoderma: A significant fungus for agriculture and environment. Af. J. Agric. Res. 11(22), 1952-1965.

170.Wang, S.L. \& Zhao, X.Y. (2009). On the potential of biological treatment for arsenic contaminated soils and 
groundwater. J. Environ. Manage. 90(8), 2367-2376.

171.Wang, Y., Zhang, C., Zheng, Y. \& Ge, Y. (2017). Bioaccumulation kinetics of arsenite and arsenate in Dunaliella salina under different phosphate regimes. Environ. Sci. Pollut. Res. 24(26), pp.21213-21221.

172.WOOLSON, E.A. (1983). Emissions, cycling and effects of arsenic in soils (pp. 51-139). Elsevier, Amsterdam.

173.WRUD (2001). Preliminary Study on Arsenic Contamination in Selected Areas of Myanmar. Report of the Water Resources Utilization Department, Ministry of Agriculture and Irrigation, Myanmar.

174.Wu, F., Hu, J., Wu, S. \& Wong, M.H. (2015). Grain yield and arsenic uptake of upland rice inoculated with arbuscular mycorrhizal fungi in As-spiked soils. Environ. Sci. Pollut. Res. 22(12), 8919-8926.

175.Wu, Q. S. \& Zou, Y.N. (2009). Mycorrhiza has a direct effect on reactive oxygen metabolism of drought-stressed citrus. Plant Soil Environ. 55(10), 436-442.

176.Wu, Q., Wang, S., Thangavel, P., Li, Q., Zheng, H., Bai, J. \& Qiu, R. (2011). Phytostabilization potential of Jatropha curcas L. in polymetallic acid mine tailings. Int. J. Phytorem., 13(8), 788-804.

177.Wuana, R. A. \& Okieimen, F. E. (2011). Heavy metals in contaminated soils: a review of sources, chemistry, risks and best available strategies for remediation. Int. Sch. Res Notices. 2011.

178.Xiao, X. Y., Chen, T. B., Liao, X. Y., Wu, B., Yan, X. L., Zhai, L.M., Xie, H. \& Wang, L.X. (2008). Regional distribution of arsenic contained minerals and arsenic pollution in China. Geograp. Res., 27(1), pp.201-212.

179.Xie, Z., Lu, G., Liu, J., Yan, Z., Ma, B., Zhang, Z. \& Chen, W.(2015). Occurrence, bioaccumulation, and trophic magnification of pharmaceutically active compounds in Taihu Lake, China. Chemosphere, 138, 140-147.

180.Xue, X.M., Yan, Y., Xiong, C., Raber, G., Francesconi, K., Pan, T., Ye, J. \& Zhu, Y.G. (2017). Arsenic biotransformation by a cyanobacterium Nostoc sp. PCC 7120. Environ. Pollut. 228, 111-117.

181.Yamaji, N. \& Ma, J.F.(2011). Further characterization of a rice silicon efflux transporter, Lsi2. Soil Sci. Plant Nutr. 57 (2), 259-264.

182.Yan, L., Hu, H., Zhang, S., Chen, P., Wang, W. \& Li, H. (2017). Arsenic tolerance and bioleaching from realgar based on response surface methodology by Acidithiobacillus ferrooxidans isolated from Wudalianchi volcanic lake, northeast China. Electron. J. Biotechnol., 25, pp.50-57.

183.Yan, Y., Ye, J., Xue, X.M. \& Zhu, Y. G. (2015). Arsenic demethylation by a C.As lyase in cyanobacterium Nostoc sp. PCC 7120. Environ. Sci. Technol. 49(24), 1435014358.

184.Yang, H. C.\& Rosen, B. P. (2016). New mechanisms of bacterial arsenic resistance. Biomed. J. 39(1), 5-13.

185. Yin, X., Wang, L., Zhang, Z., Fan, G., Liu, J., Sun, K. \& Sun, G.X. (2017). Biomethylation and volatilization of arsenic by model protozoan Tetrahymena pyriformis under different phosphate regimes. Int. J. Environ. Res. Public Health, 14(2), p.188.

186.Yin, X. X., Chen, J., Qin, J., Sun, G. X., Rosen, B. P. \& Zhu, Y.G. (2011). Biotransformation and volatilization of arsenic by three photosynthetic cyanobacteria. Plant physiol. 156(3), 1631-1638.

187.Yoshizuka, K., Nishihama, S. \& Sato, H. (2010). Analytical survey of arsenic in geothermal waters from sites in Kyushu, Japan, and a method for removing arsenic using magnetite. Environ. Geochem. Health, 32(4), 297-302.

188.Zhang, X., Ren, B.H., Wu, S.L., Sun, Y.Q., Lin, G. \& Chen, B.D. (2015). Arbuscular mycorrhizal symbiosis influences arsenic accumulation and speciation in Medicago truncatula L. in arsenic-contaminated soil. Chemosphere, 119, 224-230.

189.Zhang, Z., Guo, H., Liu, S., Weng, H., Han, S. \& Gao, Z. (2020). Mechanisms of groundwater arsenic variations induced by extraction in the western Hetao Basin, Inner Mongolia, China. J. Hydrol. 583, 124599

190.Zhao, F. J., McGrath, S. P. \& Meharg, A. A. (2010). Arsenic as a food chain contaminant: mechanisms of plant uptake and metabolism and mitigation strategies. Ann. Rev. Plant Biol. 61, 535-559.

191.Zhu, F., Yang, M., Luo, Z.. X., Yu, R. L., Hu, G. R. \& Yan, Y. (2020). Bioaccumulation and biotransformation of arsenic in Leptolyngbya boryana. Environ. Sci. Pollut. Res. 27, pp. 29993-30000.

192.Zubair, M., Martyniuk, C. J. \& Shaheen, A. (2018). Rising level of arsenic in water and fodder: A growing threat to livestock and human populations in Pakistan. Toxin Reviews, 37(3), 171-181.

193.Zuzolo, D., Cicchella, D., Demetriades, A., Birke, M., Albanese, S., Dinelli, E., Lima, A., Valera, P. \& De Vivo, B. (2020). Arsenic: Geochemical distribution and agerelated health risk in Italy. Environ. Res. 182, 109076. 